\title{
Thermokarst amplifies fluvial inorganic carbon cycling and export across watershed scales on the Peel Plateau, Canada
}

\author{
Scott Zolkos ${ }^{1, \text { a }}$, Suzanne E. Tank ${ }^{1}$, Robert G. Striegl ${ }^{2}$, Steven V. Kokelj ${ }^{3}$, Justin Kokoszka ${ }^{3}$, \\ Cristian Estop-Aragonés ${ }^{4, b}$, and David Olefeldt ${ }^{4}$ \\ ${ }^{1}$ Department of Biological Sciences, University of Alberta, Edmonton, AB, T6G 2E3, Canada \\ ${ }^{2}$ United States Geological Survey, Boulder, CO, 80303, USA \\ ${ }^{3}$ Northwest Territories Geological Survey, Yellowknife, NT, X1A 2L9, Canada \\ ${ }^{4}$ Department of Renewable Resources, University of Alberta, Edmonton, AB, T6G 2E3, Canada \\ a present address: Woodwell Climate Research Center, Falmouth, MA 02540, USA \\ b present address: Institute of Landscape Ecology, University of Münster, 48149 Münster, Germany
}

Correspondence: Scott Zolkos (sgzolkos@gmail.com)

Received: 26 March 2020 - Discussion started: 15 April 2020

Revised: 29 August 2020 - Accepted: 8 September 2020 - Published: 26 October 2020

\begin{abstract}
As climate warming and precipitation increase at high latitudes, permafrost terrains across the circumpolar north are poised for intensified geomorphic activity and sediment mobilization that are expected to persist for millennia. In previously glaciated permafrost terrain, ice-rich deposits are associated with large stores of reactive mineral substrate. Over geological timescales, chemical weathering moderates atmospheric $\mathrm{CO}_{2}$ levels, raising the prospect that mass wasting driven by terrain consolidation following thaw (thermokarst) may enhance weathering of permafrost sediments and thus climate feedbacks. The nature of these feedbacks depends upon the mineral composition of sediments (weathering sources) and the balance between atmospheric exchange of $\mathrm{CO}_{2}$ vs. fluvial export of carbonate alkalinity $\left(\Sigma\left[\mathrm{HCO}_{3}^{-}, \mathrm{CO}_{3}^{2-}\right]\right)$. Working in the fluvially incised, ice-rich glacial deposits of the Peel Plateau in northwestern Canada, we determine the effects of slope thermokarst in the form of retrogressive thaw slump (RTS) activity on mineral weathering sources, $\mathrm{CO}_{2}$ dynamics, and carbonate alkalinity export and how these effects integrate across watershed scales $(\sim 2$ to $1000 \mathrm{~km}^{2}$ ). We worked along three transects in nested watersheds with varying connectivity to RTS activity: a $550 \mathrm{~m}$ transect along a first-order thaw stream within a large RTS, a $14 \mathrm{~km}$ transect along a stream which directly received inputs from several RTSs, and a $70 \mathrm{~km}$ transect along a larger stream with headwaters that lay outside of RTS influence. In undisturbed headwaters, stream chemistry reflected $\mathrm{CO}_{2}$
\end{abstract}

from soil respiration processes and atmospheric exchange. Within the RTS, rapid sulfuric acid carbonate weathering, prompted by the exposure of sulfide- and carbonate-bearing tills, appeared to increase fluvial $\mathrm{CO}_{2}$ efflux to the atmosphere and propagate carbonate alkalinity across watershed scales. Despite covering less than $1 \%$ of the landscape, RTS activity drove carbonate alkalinity to increase by 2 orders of magnitude along the largest transect. Amplified export of carbonate alkalinity together with isotopic signals of shifting DIC and $\mathrm{CO}_{2}$ sources along the downstream transects highlights the dynamic nature of carbon cycling that may typify glaciated permafrost watersheds subject to intensification of hillslope thermokarst. The balance between $\mathrm{CO}_{2}$ drawdown in regions where carbonic acid weathering predominates and $\mathrm{CO}_{2}$ release in regions where sulfides are more prevalent will determine the biogeochemical legacy of thermokarst and enhanced weathering in northern permafrost terrains. Effects of RTSs on carbon cycling can be expected to persist for millennia, indicating a need for their integration into predictions of weathering-carbon-climate feedbacks among thermokarst terrains. 


\section{Introduction}

Riverine export of carbonate alkalinity $\left(\Sigma\left[\mathrm{HCO}_{3}^{-}, \mathrm{CO}_{3}^{2-}\right]\right)$, generated by the chemical weathering of silicate and carbonate minerals, is a key component of the global carbon cycle and Earth's long-term climate (Berner, 1999; Gaillardet et al., 1999; Hilton and West, 2020; Torres et al., 2017). The degree to which carbonate alkalinity production involves $\mathrm{CO}_{2}$ (as carbonic acid, $\mathrm{H}_{2} \mathrm{CO}_{3}=\mathrm{H}_{2} \mathrm{O}+\mathrm{CO}_{2(\mathrm{~g}, \mathrm{aq})}$ ) from atmospheric or soil respiration sources and liberates mineral carbon influences whether dissolved inorganic carbon (DIC $=\Sigma\left[\mathrm{CO}_{2}\right.$, carbonate alkalinity]) in fluvial networks represents a carbon sink or source. Rapid warming at northern latitudes (Serreze and Barry, 2011) is thawing permafrost (Biskaborn et al., 2019), increasing vegetation productivity (Bjorkman et al., 2018), intensifying hydrologic cycles (Rawlins et al., 2010), and strengthening land-fresh water linkages (Vonk et al., 2019; Walvoord and Kurylyk, 2016). These processes are activating large amounts of mineral substrate into biogeochemical cycles, with significant implications for DIC cycling (Lacelle et al., 2019; Wadham et al., 2019). In recent decades, increasing riverine fluxes of carbonate alkalinity and solutes across the circumpolar north reflect enhanced mineral weathering associated with active layer thickening, deepening hydrologic flow paths into mineral soils, and greater soil acidity from increasing vegetation productivity (Drake et al., 2018a; Tank et al., 2016; Toohey et al., 2016). Glaciated permafrost terrain hosting ice-rich deposits of reactive sediments are thought to be distributed across the northern permafrost zone, raising the prospect that terrain consolidation following thaw (thermokarst) and associated carbonate alkalinity production and export may have stronger influence on climate feedbacks in such regions (Zolkos et al., 2018).

Three coupled factors primarily influence the degree to which carbonate alkalinity represents a carbon sink or source: first, the weathering source, which accounts for both the mineral composition of substrate subjected to chemical weathering and the acid(s) responsible for weathering. Silicate weathering by $\mathrm{H}_{2} \mathrm{CO}_{3}$ generates alkalinity without liberating mineral carbon and thus represents a long-term $\mathrm{CO}_{2}$ sink. In contrast, $\mathrm{H}_{2} \mathrm{CO}_{3}$ carbonate weathering is a $\mathrm{CO}_{2}$ sink only over $\sim 10^{2}-10^{3} \mathrm{yr}$ as half of the alkalinity produced is geogenic. $\mathrm{HCO}_{3}^{-}$produced during carbonate weathering in the presence of strong acids, for instance sulfuric acid $\left(\mathrm{H}_{2} \mathrm{SO}_{4}\right)$ from sulfide oxidation, is a $\mathrm{CO}_{2}$ source over longer timescales ( $\sim 10^{6} \mathrm{yr}$; Calmels et al., 2007$)$ and can also produce $\mathrm{CO}_{2}$ over shorter timescales when $\mathrm{H}_{2} \mathrm{SO}_{4}$ is present in excess (Stumm and Morgan, 1996). The second factor is the rate of mineral weathering and processes that further alter this rate. Rates of chemical weathering are orders of magnitude faster for carbonates and sulfides than for silicates (Stumm and Morgan, 1996). Further, weathering rates generally increase with mineral surface area and therefore are often fast in glacial environments owing to intense physical weathering (Anderson, 2007). Indeed, hydrochemical signa- tures of trace carbonate and sulfide lithologies can dominate weathering fluxes in primarily silicate glacial environments (Anderson, 2007). The disparity is so significant that, when sediment supplies are sufficient, $\mathrm{H}_{2} \mathrm{CO}_{3}$ carbonate weathering in proglacial streams can consume dissolved $\mathrm{CO}_{2}$ to below atmospheric levels (Sharp et al., 1995; St. Pierre et al., 2019). The third factor is the magnitude of carbonate alkalinity export, which is influenced by its production via weathering of minerals during fluvial transport (e.g., Striegl et al., 2007) and its loss via carbonate equilibrium reactions and $\mathrm{CO}_{2}$ degassing along the land-fresh water-ocean continuum. From a climate perspective, the magnitude of carbonate alkalinity export is particularly relevant over geological timescales because half of riverine carbonate alkalinity exported to the ocean is returned to the atmosphere as $\mathrm{CO}_{2}$ via precipitation reactions within the marine carbon cycle (Calmels et al., 2007). Together, these three controls on carbonate alkalinity highlight the nonconservative nature of DIC and its susceptibility to transformation within fluvial networks. Hence, to constrain carbonate alkalinity export in rapidly changing permafrost terrains, nested-watershed sampling designs are critical for capturing DIC transformation along the land-fresh water-ocean continuum and resolving drivers and sources of carbon cycling across scales (Drake et al., 2018b).

Glaciated permafrost terrains are poised for rapid geomorphic and associated biogeochemical change as the climate warms and precipitation intensifies (Kokelj et al., 2017b). Despite glacial retreat across much of the circumpolar north, permafrost within these landscapes preserves biogeochemical legacies of glaciation across northern Canada, Alaska, and western Siberia (Kokelj et al., 2017b). In North America, the comminution of carbonate and shale bedrock during expansion of the Laurentide Ice Sheet (LIS) and the climate and vegetative protection of ice- and sediment-rich tills in the wake of its retreat endowed former glacial margins across northwestern Canada with thick inorganic tills held in ice-rich permafrost (Kokelj et al., 2017b). Today, the climate-driven renewal of postglacial landscape change is mobilizing immense stores of minerals into modern biogeochemical cycles via hillslope thermokarst features, the largest of which include retrogressive thaw slumps (RTSs; Kokelj et al., 2017a). On the Peel Plateau (NWT, Canada), RTSs expose carbonate- and sulfide-bearing glaciogenic permafrost sediments that are tens of meters thick. The chemical weathering and fluvial transport of these sediments results in increased $\mathrm{HCO}_{3}^{-}$immediately downstream of RTSs and greater solute and sediment loads throughout downstream systems (Kokelj et al., 2013; Malone et al., 2013; Zolkos et al., 2018). RTS activity has been suggested - but not previously proved to be - partly responsible for increasing carbonate alkalinity fluxes in the larger Peel River during recent decades (Zolkos et al., 2018). Yet, it remains unknown how hillslope thermokarst effects on mineral weathering and DIC sources and cycling integrate across watershed scales on the 

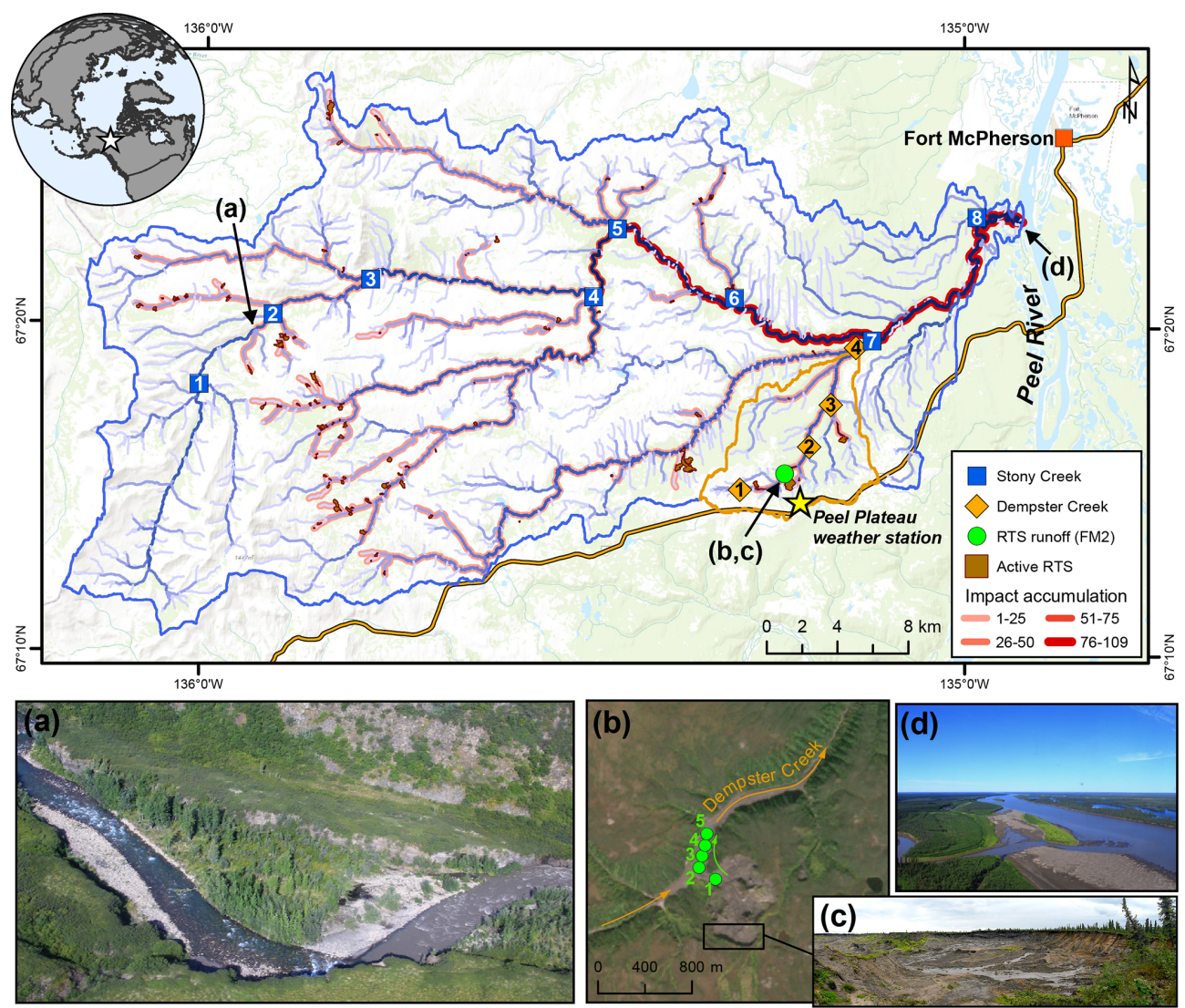

Figure 1. Sampling sites on the Peel Plateau (NWT, Canada). Water samples were collected along the main stem of Dempster and Stony creeks $(n=12)$ and major tributaries $(n=10)$ and from the rill runoff at retrogressive thaw slump (RTS) FM2. Numbers within symbols are sampling sites (Tables 1 and A1). RTS impact accumulation represents the number of active RTSs affecting upstream reaches $(n=109$; see Methods Sect. 2.6). (a) Aerial photograph of Stony Creek where it was first impacted by RTS activity. (b) RTS FM2 runoff transect sampling scheme. RTS FM2 spans $\sim 40$ ha, its headwall (c) reaches $\sim 25 \mathrm{~m}$ in height, and the debris tongue contains $2 \times 10^{6} \mathrm{~m}^{3}$ of sediment $($ van der Sluijs et al., 2018). (d) Aerial photograph of Stony Creek (lower left) flowing into the Peel River. Satellite image of RTS FM2 in September 2017 (b) obtained from Copernicus Sentinel data (European Space Agency, https://sentinel.esa.int/, last access: 25 March 2020). Base map: Esri ArcGIS Online $\subset$ OpenStreetMap contributors, GIS User Community.

Peel Plateau and in relatively inorganic-rich permafrost terrains across the circumpolar north. In this study we evaluated trends in major ions, DIC concentration, and dual $\delta^{13} \mathrm{C}-\mathrm{DIC}-$ $\delta^{13} \mathrm{C}-\mathrm{CO}_{2}$ isotopes along transects within three nested watersheds in the Stony Creek watershed on the Peel Plateau. Our nested watershed approach was intended to allow us to determine how RTS effects on carbon cycling integrate across scales from $\sim 1$ to $1000 \mathrm{~km}^{2}$.

\section{Methods}

\subsection{Study area}

The Stony Creek watershed is located southwest of the hamlet of Fort McPherson, in the northern or lower Peel River watershed (Fig. 1). Stony Creek, a tributary of the Peel River, originates in the Richardson Mountains, where slopes are sparsely vegetated and mainly consist of bedrock col- luvium (Duk-Rodkin and Hughes, 1992). Exposed marine shale and sandstone bedrock contain sulfide- and gypsumbearing lithologies but limited carbonate (Norris, 1985). As Stony Creek flows eastward, the main channel and its tributaries incise ice-rich glacial deposits and underlying Cretaceous bedrock, forming a stream network comprised of tundra flow tracks grading to incised gravel bed streams with increasing watershed size. The fluvially incised valleys and increasing regional precipitation have proven conducive to thaw-driven mass wasting of ice-rich glacial deposits and formation of RTSs (Kokelj et al., 2017b). Growth of RTSs is driven by the ablation of exposed ground ice and is perpetuated by the downslope mass wasting of thawed material via fluidized earth flows, which can accumulate large volumes of debris in stream valleys (Fig. 1). Across the Stony Creek watershed, intensifying RTS activity releases large volumes of sediment and solutes into streams relative to undisturbed headwaters (Kokelj et al., 2017b; Segal et al., 2016). This 
substrate is transported to streams via rill runoff channels in the scar zone and debris tongue deposits in the stream valley. Impacts to Stony Creek are representative of numerous other major Peel River tributaries that have incised the icerich Peel Plateau (Kokelj et al., 2015). The $\sim 60 \mathrm{~km}^{2}$ watershed of Dempster Creek, a tributary of Stony Creek, originates in willow and open spruce taiga without RTS activity, receiving large inputs of sediments and solutes from RTSs FM2 and FM3 within several kilometers of the headwaters (Kokelj et al., 2013; Malone et al., 2013). Many small, nonRTS-affected streams and several larger RTS-affected tributaries flow into Dempster Creek before its confluence with Stony Creek.

\subsection{Stream sampling}

In late July 2017, we sampled along transects within three nested watersheds (Fig. 1, Table A1) to understand how the effects of RTSs integrate across watershed scales. (i) The RTS FM2 runoff transect included five sampling locations along a $550 \mathrm{~m}$ long thaw stream formed by a runoff channel within an active RTS. The RTS FM2 runoff received no observable hydrologic inputs during the sampling period. (ii) A $14 \mathrm{~km}$ transect along the main stem of Dempster Creek, which received inputs directly from RTS FM2, was sampled at one location in undisturbed headwaters and at three sites downstream of RTS FM2. Sites downstream were located on the main stem, immediately upstream of three major tributaries. We also sampled from the tributaries near their confluence with Dempster Creek to characterize tributary chemistry. (iii) A $70 \mathrm{~km}$ transect along the main stem of Stony Creek, a sixth-order stream, was sampled at eight locations: one in undisturbed headwaters and seven on the RTS-affected reach upstream of major tributaries. We additionally sampled from one tributary of the undisturbed headwaters and from six RTS-affected tributaries near their confluence with the main stem. Stony Creek, a major tributary of the $70000 \mathrm{~km}^{2}$ Peel River watershed (Fig. 1), was sampled to determine how the effects of RTS activity on DIC integrate across broader scales.

At all sampling sites, stream temperature, specific conductance (henceforth, "conductivity"), and pH were measured using a precalibrated YSI Professional Plus water quality meter. At most sites, water samples were collected for ions, DIC, $\mathrm{CO}_{2}, \mathrm{CH}_{4}$, dissolved organic carbon (DOC), UV-visible absorbance, and total suspended solids (TSS). Along the RTS FM2 runoff transect, we sampled only for DIC and $\mathrm{CO}_{2}$ concentration and stable isotopes of dissolved $\mathrm{CO}_{2}\left(\delta^{13} \mathrm{C}-\mathrm{CO}_{2}\right)$. Additional parameters were sampled $1 \mathrm{~d}$ prior at RTS FM2 runoff site 5, located near the confluence of the RTS runoff with Dempster Creek, for comparison with the full suite of chemistry parameters collected along the Dempster Creek transect. At the Dempster and Stony Creek sites, we additionally sampled water for stable isotopes of DIC $\left(\delta^{13} \mathrm{C}\right.$-DIC) and used dual $\delta^{13} \mathrm{C}$-DIC- $-{ }^{13} \mathrm{C}-\mathrm{CO}_{2}$ isotopes to characterize abiotic and biotic processes influencing DIC sources and cycling across watershed scales.

Water samples were collected from the thalweg where possible as an integrated sample from $\sim 15 \mathrm{~cm}$ below the surface to $\sim 1 \mathrm{~m}$ depth. An additional sample for TSS was collected in a $1 \mathrm{~L}$ high-density polyethylene (HDPE) bottle in the same fashion. Water samples were filtered using sample-rinsed $0.45 \mu \mathrm{m}$ polyethersulfone (PES; ThermoFisher) or cellulose acetate (CA; Sartorius) membranes. Samples for DIC were collected without headspace in airtight syringes. Samples for ions, DOC, and UV-visible absorbance were collected in acid-washed $(24 \mathrm{~h}, 10 \% v / v \mathrm{HCl})$ all-plastic syringes. Syringes were triple sample-rinsed, sealed without headspace, and stored cool and dark until processing within $10 \mathrm{~h}$. Water for DIC was filtered (PES) into precombusted $\left(5 \mathrm{~h}, 500^{\circ} \mathrm{C}\right)$ glass vials without headspace and sealed with a butyl rubber septum for DIC concentration or two silicone-teflon septa for $\delta^{13} \mathrm{C}$-DIC. Samples for cations were filtered (CA) into acidwashed bottles and acidified with trace metal-grade $\mathrm{HNO}_{3}$, while anions were filtered (CA) but not acidified. Samples for DOC were filtered (PES) into precombusted glass vials and acidified to $\mathrm{pH}<2$ using trace metal-grade $\mathrm{HCl}$ (Vonk et al., 2015). Samples for UV-visible absorbance were filtered (PES) into nonacid-washed $30 \mathrm{~mL}$ HDPE bottles. Samples were refrigerated $\left(4^{\circ} \mathrm{C}\right.$, dark) until analysis.

Dissolved gases were collected following the headspace equilibration method (Hesslein et al., 1991) and stored in airtight syringes (for $\mathrm{CO}_{2}$ concentration) or overpressurized in pre-evacuated serum bottles sealed with prebaked $\left(60^{\circ} \mathrm{C}\right.$, $12 \mathrm{~h}$ ), gas-inert butyl rubber stoppers (for $\delta^{13} \mathrm{C}_{-} \mathrm{CO}_{2}, \mathrm{CH}_{4}$ ). At each site, atmospheric samples for $\mathrm{CO}_{2}$ and $\mathrm{CH}_{4}$ concentration and $\delta^{13} \mathrm{C}-\mathrm{CO}_{2}$ were stored in the same fashion. Gas samples were stored in the dark at $\sim 20^{\circ} \mathrm{C}$ prior to analysis within $10 \mathrm{~h}\left(\mathrm{CO}_{2}\right)$ or 2 months $\left(\delta^{13} \mathrm{C}-\mathrm{CO}_{2}, \mathrm{CH}_{4}\right)$. Water and air temperature, atmospheric pressure, and the volumetric ratio of sample to atmospheric headspace were recorded for correcting later calculations of $\mathrm{CO}_{2}$ partial pressure $\left(p \mathrm{CO}_{2}\right)$ and $\delta^{13} \mathrm{C}-\mathrm{CO}_{2}$ (Hamilton and Ostrom, 2007).

\subsection{Hydrochemical analyses}

Upon returning from the field each day, $\mathrm{CO}_{2}$ was measured using an infrared gas analyzer (PP Systems EGM-4), which was checked monthly for drift using a commercial standard (Scotty Gases). We calculated $p \mathrm{CO}_{2}$ using Henry's constants, corrected for stream water temperature (Weiss, 1974) and accounting for the ratio of water volume to headspace during sample equilibration. DIC samples were measured by infrared $\mathrm{CO}_{2}$ detection (LiCOR 7000) following acidification within a DIC analyzer (Apollo SciTech model AS-C3). Calibration curves were made daily using certified reference material (CRM) from the Scripps Institution of Oceanography. Samples with DIC concentrations $<400 \mu \mathrm{M}$ were analyzed using solutions prepared from a $1000 \mathrm{ppm}$ TIC stock (ACCUSPEC) that were calibrated with CRM. DIC species 
Table 1. Mineral weathering equations used to create Piper diagram end-members. $\mathrm{H}_{2} \mathrm{CO}_{3}$ : carbonic acid; $\mathrm{H}_{2} \mathrm{SO}_{4}:$ sulfuric acid. $\mathrm{H}_{2} \mathrm{CO}_{3}$ includes dissolved $\mathrm{CO}_{2}(\mathrm{~g})$.

\begin{tabular}{|c|c|c|c|}
\hline Equation & Reaction & Reaction equation & Reference \\
\hline 1 & $\mathrm{H}_{2} \mathrm{CO}_{3}$ carbonate weathering $(\mathrm{CACW})$ & $\mathrm{H}_{2} \mathrm{CO}_{3}+(\mathrm{Ca}, \mathrm{Mg}) \mathrm{CO}_{3} \rightarrow\left(\mathrm{Ca}^{2+}, \mathrm{Mg}^{2+}\right)+2 \mathrm{HCO}_{3}^{-}$ & Lehn et al. (2017) \\
\hline 2 & $\mathrm{H}_{2} \mathrm{CO}_{3}$ silicate weathering (CASW) & $2 \mathrm{H}_{2} \mathrm{CO}_{3}+3 \mathrm{H}_{2} \mathrm{O}+(\mathrm{Ca}, \mathrm{Mg}) \mathrm{Al}_{2} \mathrm{Si}_{2} \mathrm{O}_{8} \rightarrow\left(\mathrm{Ca}^{2+}, \mathrm{Mg}^{2+}\right)+2 \mathrm{HCO}_{3}^{-}+2 \mathrm{Al}_{2} \mathrm{Si}_{2} \mathrm{O}_{5}(\mathrm{OH})_{4}$ & Lehn et al. (2017) \\
\hline 3 & $\mathrm{H}_{2} \mathrm{SO}_{4}$ carbonate weathering (SACW) & $\mathrm{H}_{2} \mathrm{SO}_{4}+2(\mathrm{Ca}, \mathrm{Mg}) \mathrm{CO}_{3} \rightarrow 2\left(\mathrm{Ca}^{2+}, \mathrm{Mg}^{2+}\right)+\mathrm{SO}_{4}^{2-}+2 \mathrm{HCO}_{3}^{-}$ & Lehn et al. (2017) \\
\hline 4 & $\mathrm{H}_{2} \mathrm{SO}_{4}$ silicate weathering (SASW) & $\mathrm{H}_{2} \mathrm{SO}_{4}+\mathrm{H}_{2} \mathrm{O}+(\mathrm{Ca}, \mathrm{Mg}) \mathrm{Al}_{2} \mathrm{Si}_{2} \mathrm{O}_{8} \rightarrow\left(\mathrm{Ca}^{2+}, \mathrm{Mg}^{2+}\right)+\mathrm{SO}_{4}^{2-}+\mathrm{Al}_{2} \mathrm{Si}_{2} \mathrm{O}_{5}(\mathrm{OH})_{4}$ & Lehn et al. (2017) \\
\hline 5 & Sulfate salt dissolution (SSD) & $(\mathrm{Ca}, \mathrm{Mg}) \mathrm{SO}_{4} \rightarrow\left(\mathrm{Ca}^{2+}, \mathrm{Mg}^{2+}\right)+\mathrm{SO}_{4}^{2-}$ & Lehn et al. (2017) \\
\hline 6 & Sulfide oxidation & $\mathrm{FeS}_{2}+15 / 4 \mathrm{O}_{2}+7 / 2 \mathrm{H}_{2} \mathrm{O} \rightarrow \mathrm{Fe}\left(\mathrm{OH}_{3}\right)+2 \mathrm{H}^{+}+\mathrm{SO}_{4}^{2-}$ & Calmels et al. (2007) \\
\hline 7 & $\begin{array}{l}\text { Carbonate weathering by } \mathrm{H}_{2} \mathrm{SO}_{4} \\
\text { in excess }\left(\mathrm{SA}_{\mathrm{ex}} \mathrm{CW}\right)\end{array}$ & $2 \mathrm{H}_{2} \mathrm{SO}_{4}+\mathrm{CaMg}\left(\mathrm{CO}_{3}\right)_{2} \rightarrow \mathrm{Ca}^{2+}+\mathrm{Mg}^{2+}+2 \mathrm{SO}_{4}^{2-}+2 \mathrm{H}_{2} \mathrm{CO}_{3}$ & Stallard and Edmond (1983) \\
\hline 8 & Carbonate equilibrium/DIC speciation & $\mathrm{H}_{2} \mathrm{O}+\mathrm{CO}_{2(\mathrm{~g})} \rightleftharpoons \mathrm{H}_{2} \mathrm{CO}_{3} \rightleftharpoons \mathrm{H}^{+}+\mathrm{HCO}_{3}^{-} \rightleftharpoons 2 \mathrm{H}^{+}+\mathrm{CO}_{3}^{2-}$ & Stumm and Morgan (1996) \\
\hline
\end{tabular}

$\left(\mathrm{CO}_{2}, \mathrm{HCO}_{3}^{-}, \mathrm{CO}_{3}^{2-}\right)$ were calculated from DIC concentration and $p \mathrm{CO}_{2}$ or $\mathrm{pH}$ using CO2SYS (v.2.3; Pierrot et al., 2006) as well as field temperature and pressure at the time of sampling and the freshwater equilibrium constants for K1 and K2 (Millero, 1979).

Cations and trace elements were measured by optical emission spectrometry (Thermo ICAP-6300) and anions by ion chromatography (Dionex DX-600) at the University of Alberta Biogeochemical Analytical Services Laboratory (BASL, ISO/EIC accreditation no. 17025). DOC was measured using a total-organic-carbon analyzer (Shimadzu TOCV). DOC standard curves were made daily with a $1000 \mathrm{ppm}$ KHP solution (ACCUSPEC), and an in-house caffeine standard $\left(10 \mathrm{mg} \mathrm{L}^{-1}\right)$ was run every 20 samples to monitor instrument drift. Absorbance spectra were analyzed using an Ocean Optics UV-VIS instrument with a Flame spectrometer module, following Stubbins et al. (2017) and corrected for Fe interference (Poulin et al., 2014). To evaluate organic carbon reactivity, we used specific ultraviolet absorbance at $254 \mathrm{~nm}$ $\left(\mathrm{SUVA}_{254}\right.$ ) to infer DOC aromaticity (Weishaar et al., 2003).

$\delta^{13} \mathrm{C}$-DIC was determined using an isotope ratio mass spectrometer (Finnigan Mat DeltaPlusXP) interfaced to a total-organic-carbon analyzer (OI Analytical Aurora Model 1030W) at the University of Ottawa Stable Isotope Laboratory. $\delta^{13} \mathrm{C}-\mathrm{CO}_{2}$ and the concentration of $\mathrm{CH}_{4}$ were analyzed within 2 months using a Picarro isotope analyzer (G2201-i $;<0.2 \%$ o precision, $\mathrm{CH}_{4}$ operational range $=1.8$ $1500 \mathrm{ppm}$ ) equipped with a Small Sample Introduction Module. Commercial $\delta^{13} \mathrm{C}-\mathrm{CO}_{2}$ and $\mathrm{CH}_{4}$ standards were used to check for drift during each run. We used mass balance to correct $\delta^{13} \mathrm{C}-\mathrm{CO}_{2}$ values for the $\delta^{13} \mathrm{C}$ and mass of atmospheric $\mathrm{CO}_{2}$ used for equilibration (Hamilton and Ostrom, 2007). To assess $\delta^{13} \mathrm{C}-\mathrm{CO}_{2}$ fractionation from calcite precipitation (Turner, 1982) and methanogenesis (Campeau et al., 2018) in RTS FM2 runoff, we calculated the saturation index (SI) and partial pressure of $\mathrm{CH}_{4}\left(p \mathrm{CH}_{4}\right)$. SI was calculated using the hydrochemical software Aqion version 6.7.0 (https: //www.aqion.de, last access: 15 October 2018), which uses the US Geological Survey software PHREEQC (Parkhurst and Appelo, 2013) as the internal numerical solver. Samples for atmospheric and dissolved $\mathrm{CH}_{4}$ were collected in the same fashion as $\delta^{13} \mathrm{C}-\mathrm{CO}_{2} \cdot p \mathrm{CH}_{4}$ was calculated using Bunsen solubility coefficients (Wiesenburg and Guinasso, 1979) converted to the appropriate units (Sander, 2015).

TSS samples were filtered onto muffled $\left(450^{\circ} \mathrm{C}, 4 \mathrm{~h}\right)$ and preweighed glass fiber filters (Whatman GF/F; $0.7 \mu \mathrm{m}$ nominal pore size) upon returning from the field, stored frozen, and dried $\left(60^{\circ} \mathrm{C}, 24 \mathrm{~h}\right)$ for gravimetric analysis following a modified version of US Geological Survey Method I-3765.

\subsection{Mineral weathering and DIC sources}

We used a Piper diagram (Piper, 1944), which reflects the proportional equivalent concentrations of ions in a sample relative to mineral weathering end-members, as one method to constrain the sources of mineral weathering and $\mathrm{HCO}_{3}^{-}$. The products of Eqs. (1)-(7) defined the mineral weathering end-members in the Piper diagram (Table 1). We further constrained mineral weathering and DIC sources using $\delta^{13} \mathrm{C}$ $\mathrm{DIC}$ and $\mathrm{pH}$. End-member $\delta^{13} \mathrm{C}$-DIC ranges for equilibrium processes (mixing with atmospheric and/or biotic $\mathrm{CO}_{2}$ ) and kinetic reactions (mineral weathering) were derived following Lehn et al. (2017) and using published isotopic fractionation factors (Zhang et al., 1995).

To evaluate potential effects on $\delta^{13} \mathrm{C}-\mathrm{CO}_{2}$ from DIC speciation along the $\mathrm{pH}$ continuum (Eq. 8, Table 1; Clark and Fritz, 1997), we compared theoretical and observed $\delta^{13} \mathrm{C}$ $\mathrm{CO}_{2}$ values in the Stony Creek main stem. Theoretical $\delta^{13} \mathrm{C}_{-} \mathrm{CO}_{2}$ values were calculated using mass balance to obtain $\delta^{13} \mathrm{C}-\mathrm{HCO}_{3}^{-}$from measurements of DIC, $\mathrm{CO}_{2}, \mathrm{HCO}_{3}^{-}$, $\delta^{13} \mathrm{C}$-DIC, and $\delta^{13} \mathrm{C}_{-} \mathrm{CO}_{2}$. We then used measurements of stream temperature $(T)$ to calculate the equilibrium fractionation between $\mathrm{CO}_{2}$ and $\mathrm{HCO}_{3}^{-}\left(\varepsilon=-9.483 \times 10^{3} / T+\right.$ $23.89 \%$; Mook et al., 1974). Finally, $\varepsilon$ was subtracted from ${ }^{13} \mathrm{C}-\mathrm{HCO}_{3}^{-}$to obtain theoretical $\delta^{13} \mathrm{C}-\mathrm{CO}_{2}$. Similarity between observed and theoretical $\delta^{13} \mathrm{C}-\mathrm{CO}_{2}$ values was interpreted as $\delta^{13} \mathrm{C}-\mathrm{CO}_{2}$ variability driven by carbonate equilibrium reactions, whereas dissimilarity was taken to reflect effects from $\mathrm{CO}_{2}$ degassing (Zhang et al., 1995) and/or biotic $\mathrm{CO}_{2}$ production (Kendall et al., 2014). 


\subsection{Geospatial analyses}

Stream networks and watershed areas were delineated using the ArcHydro tools in ArcGIS 10.5 from the gridded $(30 \mathrm{~m})$ Canadian Digital Elevation Model (CDEM). CDEM data were reconditioned using National Hydro Network stream vectors, which were first modified as needed to align with stream flow paths visible in Copernicus Sentinel2 multispectral satellite imagery from 2017 (European Space Agency, https://sentinel.esa.int/, last access: 25 March 2020). To statistically assess landscape controls on DIC cycling (Sect. 2.7), we delineated active RTSs and derived terrain roughness and vegetation productivity in the major tributary watersheds of Stony Creek. RTSs were interpreted as active where exposed sediment visibly dominated the feature surface (Cray and Pollard, 2015) in orthorectified Satellite Pour l'Observation de la Terre (SPOT) multispectral imagery that we pan-sharpened to $1.6 \mathrm{~m}$ resolution using the ArcGIS Image Analysis tool. The satellite imagery was collected from 9 to 25 September 2016. Active RTSs that were connected to streams were manually delineated using ArcGIS. We used RivEx 10.25 software (Hornby, 2017) to quantify the number of active RTSs impacting streams in the Stony Creek watershed and to visualize the accumulation of RTS impacts across the fluvial network. We defined RTS impact accumulation as the cumulative number of active RTSs impacting upstream reaches. RTSs were interpreted to impact streams based on contact with the channel or interpreted downslope flow based on slope direction and gradient from the CDEM (Supplement). Where a single RTS affected multiple streams, only the upstream segment was used for the accumulation.

We used the Geomorphic and Gradients Metrics Toolbox (Evans et al., 2014) to calculate terrain roughness, which is a measure of variance across a land surface and represents topographic complexity (Riley et al., 1999). We use terrain roughness as a proxy for potential physical erosion, which is known to enhance sulfide oxidation by exposing shale regolith throughout the Peel River watershed (Calmels et al., 2007) and may therefore influence DIC. The enhanced vegetation index (EVI) was used to broadly evaluate vegetation productivity (Huete et al., 2002), which is known to influence DIC production by enhancing mineral weathering (Berner, 1999). We used the US National Aeronautics and Space Administration EVI product (Didan, 2015), which is derived from the gridded $(250 \mathrm{~m})$ moderate-resolution imaging spectroradiometer (MODIS). The MODIS data were collected on 28 July 2017. The ArcGIS Zonal Statistics tool was used to calculate total RTS area, mean terrain roughness, and mean EVI in Stony Creek tributary watersheds.

\subsection{Stream flow}

Water discharge $(Q)$ in Stony Creek tributaries was estimated from a hydraulic-geometry model (Gordon et al., 2004) that we developed using flow measurements made in Peel Plateau streams during 2015-2017, and width $(W)$ was estimated from on-site measurements or photos from 2017 with a known scale. The model reflected measurements spanning diverse stream morphologies $(W=0.4-6.6 \mathrm{~m})$ and flow conditions $\left(Q=0.005-0.91 \mathrm{~m}^{3} \mathrm{~s}^{-1} ;\right.$ Fig. A1):

$Q=e^{\ln (W / 6.258) / 0.661}\left(p<0.001, R^{2}=0.89, F_{1,18}=150\right)$.

Discharge values from 2015 to 2017 were calculated from measurements of stream flow (RedBack Model RB1, PVD100) and cross-sectional area made at increments equal to $10 \%$ of stream width (Gordon et al., 2004; Lurry and Kolbe, 2000) and were averaged for sites with multiple measurements.

\subsection{Statistics}

We tested for downstream change in $\mathrm{HCO}_{3}^{-}$concentration and $p \mathrm{CO}_{2}$ along the Stony Creek main stem using the nonparametric Mann-Kendall test from the R software (R Core Team, 2018) package zyp (Bronaugh and Werner, 2013) following the trend prewhitening approach detailed by Yue et al. (2002) to account for serial autocorrelation. We developed a multiple linear regression model to evaluate the influence of RTS activity on $\mathrm{HCO}_{3}^{-}$export in Stony Creek tributary watersheds relative to other landscape variables known to influence DIC production, including hydrology, terrain roughness, and vegetation productivity (Berner, 1992; Drake et al., 2018a). To account for potential effects of varying tributary watershed areas on discharge $(Q)$ and constituent concentration, we used tributary $\mathrm{HCO}_{3}^{-}$yields in the model. Instantaneous discharge $\left(Q ; \mathrm{m}^{3} \mathrm{~s}^{-1}\right)$ was estimated from the hydraulic-geometry relationship between $Q$ and stream width (Eq. 1). Discharge and $\mathrm{HCO}_{3}^{-}$flux (concentration. $Q$ ) were normalized to the respective tributary watershed area and scaled to estimate daily water yield $\left(\mathrm{cm} \mathrm{d}^{-1}\right)$ and $\mathrm{HCO}_{3}^{-}$ yield $\left(\mu \mathrm{mol} \mathrm{m} \mathrm{m}^{-2} \mathrm{~d}^{-1}\right)$. Daily $\mathrm{HCO}_{3}^{-}$yields in Stony Creek tributaries were modeled as

$\mathrm{HCO}_{3}^{-}$yield $=\mathrm{RTS}_{n}+\mathrm{RTS}_{\text {area }}+$ Water yield $+\mathrm{TR}+\mathrm{EVI}$,

where $\mathrm{RTS}_{n}$ is the number of active RTSs, RTS area is the watershed area disturbed by RTSs (\%), TR is the mean terrain roughness $(\mathrm{m})$, and EVI is the mean enhanced vegetation index $(-1$ to 1$)$. The multiple linear regression was trimmed using the step function in the R package lmerTest (Kuznetsova et al., 2018) to eliminate covariates which did not improve the model. Highly collinear covariates were identified using a variance inflation factor $>3$ (Zuur et al., 2010) and removed from the trimmed models. Model fits were inspected visually with residual plots, and covariates were transformed as needed to meet assumptions of independent and homoscedastic residuals (Zuur, 2009). To understand potential effects from variable rainfall on water yields prior to and during the $2 \mathrm{~d}$ sampling window of the Stony Creek tributaries, we inspected total rainfall in $24 \mathrm{~h}$ incre- 
ments preceding the sampling of each Stony Creek tributary. Hourly rainfall data were obtained from a Government of Northwest Territories total meteorological station located $\sim 1 \mathrm{~km}$ from the RTS FM2 (Fig. A2). Statistics were performed in the $\mathrm{R}$ programming environment (v.3.4; $\mathrm{R}$ Core Team, 2018), and significance was interpreted at $\alpha=0.05$. Summary statistics are reported as mean \pm standard error unless noted.

\section{Results}

\section{1 pH, ions, and weathering sources across watershed scales}

Geochemistry of the main stem and tributary sites are summarized in Table 2. Among sites, $\mathrm{pH}$ was generally circumneutral, and conductivity was higher in proximity to RTS activity. $\mathrm{pH}$ was highest in the RTS FM2 runoff $(7.69 \pm 0.05$, mean $\pm \mathrm{SE})$, intermediate in Dempster Creek $(7.07 \pm 0.42)$, and lowest in Stony Creek $(6.86 \pm 0.21)$. Along the RTS FM2 runoff transect, $\mathrm{pH}$ decreased from 7.72 to 7.51 between sites 1 and 2, and increased thereafter to 7.80 at site 5. $\mathrm{pH}$ in the Dempster Creek headwaters (5.82) was lower than in the RTS-affected reach (7.48 \pm 0.1$)$. In Stony Creek, $\mathrm{pH}$ increased from 5.66 in headwaters to $\sim 7.30$ at sites 6-8.

Similar to $\mathrm{pH}$, conductivity was higher in the RTS FM2 runoff $\left(1799 \pm 111 \mu \mathrm{S} \mathrm{cm}^{-1}\right)$ than in Dempster Creek $\left(520 \pm 191 \mu \mathrm{S} \mathrm{cm}^{-1}\right)$ and Stony Creek $\left(320 \pm 19 \mu \mathrm{Scm}^{-1}\right)$. Conductivity in RTS FM2 runoff increased from 1370 to $1990 \mu \mathrm{Scm}^{-1}$. Along Dempster Creek, conductivity increased from $52 \mu \mathrm{S} \mathrm{cm}^{-1}$ in the undisturbed headwaters to $958 \mu \mathrm{S} \mathrm{cm}^{-1}$ at the first site downstream of RTS FM2 and decreased downstream thereafter. In Stony Creek, conductivity decreased between the headwaters and the fourth downstream site and was relatively constant at $\sim 285 \mu \mathrm{S} \mathrm{cm}^{-1}$ along the lower reach of Stony Creek (sites 5-8).

Streams were characterized by $\mathrm{Ca}^{2+}-\mathrm{Mg}^{2+}-\mathrm{SO}_{4}^{2-}$-type waters (Fig. 2) with low concentrations of $\mathrm{Cl}^{-}$relative to $\mathrm{SO}_{4}^{2-}$, reflecting a predominance of $\mathrm{H}_{2} \mathrm{SO}_{4}$ carbonate weathering and sulfate salt (e.g., gypsum) dissolution over other mineral weathering sources. A relatively greater proportion of $\mathrm{SO}_{4}^{2-}$ than $\mathrm{HCO}_{3}^{-}$in the RTS FM2 runoff and along the upper reach of Stony Creek (sites 1-4; Fig. 2a) suggests greater sulfate salt dissolution and/or that carbonate weathering at these sites buffered less $\mathrm{H}_{2} \mathrm{SO}_{4}$ (Eq. 7) than in Dempster Creek headwaters and its tributaries (Eq. 3). Along the Stony Creek main stem (sites 1-8), increasing $\mathrm{HCO}_{3}^{-}$(Fig. 2a) reflected inputs from RTS-affected tributaries (sites 2-7) having relatively more $\mathrm{HCO}_{3}^{-}$-type waters (Fig. 2b) from $\mathrm{H}_{2} \mathrm{SO}_{4}$ and potentially $\mathrm{H}_{2} \mathrm{CO}_{3}$ carbonate weathering.

\section{2 $\mathrm{HCO}_{3}^{-}$concentration and $p \mathrm{CO}_{2}$}

Carbonate alkalinity $\left(\mathrm{HCO}_{3}^{-}+\mathrm{CO}_{3}^{2-}\right)$ was primarily $\mathrm{HCO}_{3}^{-}$ $(>99 \%)$ at all sites. $\mathrm{HCO}_{3}^{-}$was highest in the RTS FM2 runoff $(1429 \pm 23 \mu \mathrm{M})$, intermediate in Dempster Creek $(864 \pm 261 \mu \mathrm{M})$, and lowest in Stony Creek $(255 \pm 59 \mu \mathrm{M})$. Along the RTS FM2 runoff transect, $\mathrm{HCO}_{3}^{-}$decreased from 1510 to $1386 \mu \mathrm{M}$. In Dempster Creek and Stony Creek, $\mathrm{HCO}_{3}^{-}$concentrations were relatively low in undisturbed headwaters ( 115 and $33 \mu \mathrm{M}$, respectively) and 2 to 10 times higher at the first RTS-affected site (1321 and $69 \mu \mathrm{M}$, respectively). $\mathrm{HCO}_{3}^{-}$decreased along the entire RTS-affected reach of Dempster Creek (from 1321 to $946 \mu \mathrm{M}$ ) in conjunction with inputs from dozens of tributary watersheds without active RTSs. In contrast, $\mathrm{HCO}_{3}^{-}$increased significantly along Stony Creek ( $p<0.01$, Mann-Kendall test; Fig. 3a) in conjunction with inputs from RTS-affected tributaries.

$\mathrm{CO}_{2}$ was oversaturated at all sites (Fig. 3b) and a minor component of DIC $(<10 \%)$ at most sites except the undisturbed headwaters of Dempster Creek (site 1) and upper Stony Creek (sites 1-3). $p \mathrm{CO}_{2}$ was highest in the Dempster Creek headwaters $(2467 \mu \mathrm{atm})$, relatively high in the RTS FM2 runoff (1023 $\pm 137 \mu \mathrm{atm})$, and consistently near atmospheric levels along Stony Creek $(479 \pm 12 \mu \mathrm{atm})$. Along the RTS FM2 runoff transect, $p \mathrm{CO}_{2}$ increased from 1046 to $1534 \mu \mathrm{atm}$ within the first $220 \mathrm{~m}$ and then decreased from 1534 to $742 \mu \mathrm{atm}$ over the final $330 \mathrm{~m}$. Along Dempster Creek, $p \mathrm{CO}_{2}$ decreased from $2467 \mu$ atm in the headwaters to $686 \mu \mathrm{atm}$ at the first RTS-affected site and further decreased to $600 \mu \mathrm{atm}$ by the end of Dempster Creek. $p \mathrm{CO}_{2}$ in Dempster and Stony Creek tributaries were generally similar to the main stem sites.

\subsection{DOC concentration and $\mathrm{SUVA}_{254}$}

DOC concentrations were highest in Dempster Creek $(933 \pm 83 \mu \mathrm{M})$, intermediate in the RTS FM2 runoff $(758 \pm 152 \mu \mathrm{M})$, and lowest in Stony Creek $(303 \pm 54 \mu \mathrm{M})$. Along the Dempster Creek transect, DOC decreased between the undisturbed headwaters $(960 \mu \mathrm{M})$ and the first RTS-affected site $(790 \mu \mathrm{M})$ and increased thereafter along the transect (to $1156 \mu \mathrm{M}$; Fig. 3c). Along Stony Creek, DOC increased significantly (from 102 to $551 \mu \mathrm{M} ; p<0.001$, Mann-Kendall test).

SUVA $_{254}$ values were lowest in the RTS FM2 runoff $\left(1.85 \pm 0.4 \mathrm{~L} \mathrm{mgC}^{-1} \mathrm{~m}^{-1}\right)$, highest in Dempster Creek $\left(3.10 \pm 0.2 \mathrm{~L} \mathrm{mgC}^{-1} \mathrm{~m}^{-1}\right)$, and intermediate in Stony Creek $\left(2.51 \pm 0.3 \mathrm{~L} \mathrm{mgC}^{-1} \mathrm{~m}^{-1}\right)$. $\mathrm{SUVA}_{254}$ values along the Dempster Creek transect followed a similar pattern to DOC, and along Stony Creek SUVA 254 values doubled (Fig. 3d). DOC and SUVA $_{254}$ increased in consecutive downstream tributaries of Stony Creek but not Dempster Creek. 


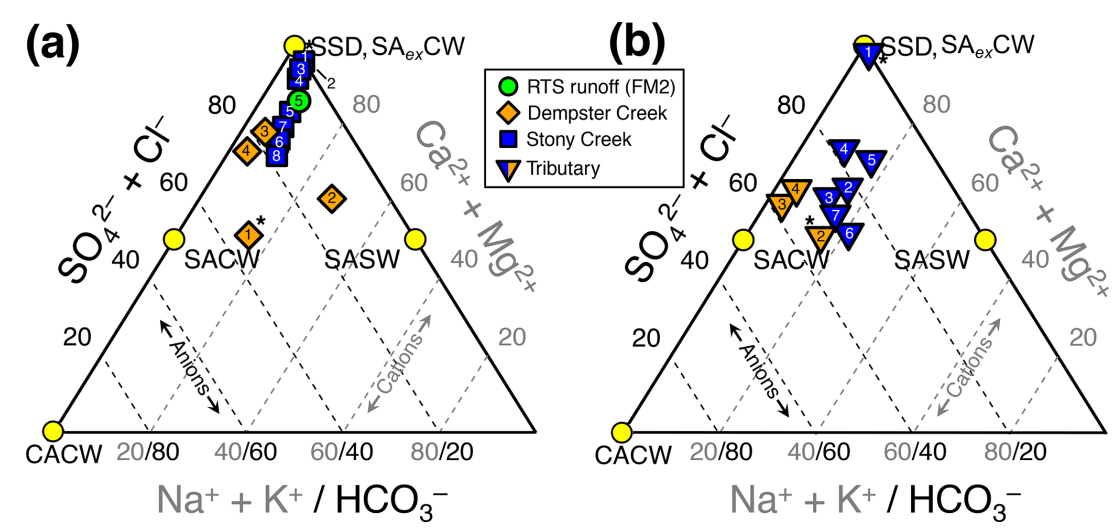

Figure 2. Piper diagrams (modified to show the upper half of the diamond plot) showing stream chemistry of the (a) main stem and retrogressive thaw slump (RTS) FM2 runoff sites and (b) tributary sites. Axes and corresponding text in gray and black reflect the proportions of cations and anions, respectively. Mineral weathering end-members were derived from the proportional concentration (meq $\mathrm{L}^{-1}$ ) of solutes generated by $\mathrm{H}_{2} \mathrm{CO}_{3}$ carbonate weathering (CACW; Eq. 1), $\mathrm{H}_{2} \mathrm{SO}_{4}$ carbonate weathering (SACW; Eq. 3), $\mathrm{H}_{2} \mathrm{SO}_{4}$ silicate weathering (SASW; Eq. 4), sulfate salt (e.g., gypsum) dissolution (SSD; Eq. 5), and carbonate weathering by $\mathrm{H}_{2} \mathrm{SO}_{4}$ in excess (SAex CW; Eq. 7). Site numbers given within symbols (Table A1). * Not RTS-affected.
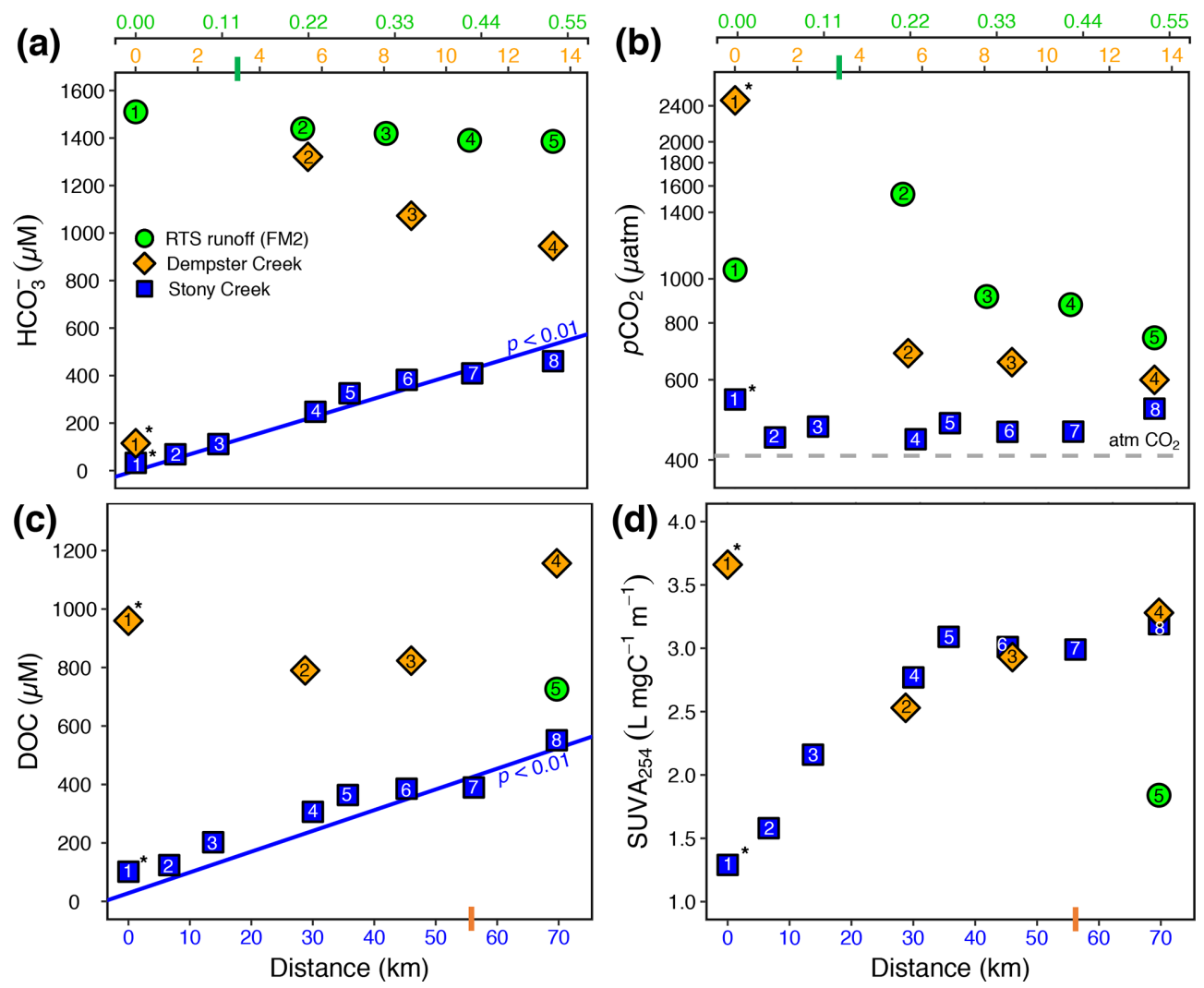

Figure 3. (a) $\mathrm{HCO}_{3}^{-}$, (b) $p \mathrm{CO}_{2}$, (c) dissolved organic carbon (DOC), and (d) SUVA 254 along the RTS FM2 runoff transect and the main stem of Stony and Dempster creeks (see locations in Fig. 1). Note different $x$-axis scales for the FM 2 runoff transect $(0-0.55 \mathrm{~km}$, upper $x$ axis), Dempster Creek (0-14 km, below RTS FM2 $x$ axis), and Stony Creek (0-70 km, lower $x$ axis). For the RTS FM2 runoff, DOC and SUVA $_{254}$ were sampled only at $0.55 \mathrm{~km}$. Regression lines in (a) and (c) are from a Mann-Kendall test (details in Sect. 2.7). Bars on $x$ axes indicate where RTS FM2 runoff enters the Dempster Creek transect (3.3 km) and where Dempster Creek enters Stony Creek (56 km). Site numbers are given within symbols (Table A1). * Not RTS-affected. 
Table 2. Geochemistry of main stem and tributary sites along Dempster and Stony creeks. Retrogressive thaw slump (RTS) FM2 runoff samples collected on 31 July 2017, except where noted. RTS FM2 runoff site 5 was nearest to the confluence with Dempster Creek (Fig. 1). Area: watershed area; SE: standard error.

\begin{tabular}{|c|c|c|c|c|c|c|c|c|c|c|c|c|c|c|c|}
\hline Type & Site & $\mathrm{pH}$ & $\begin{array}{l}\text { Cond } \\
\left(\mu \mathrm{Scm}^{-1}\right)\end{array}$ & $\begin{array}{l}p \mathrm{CO}_{2} \\
(\mu \mathrm{atm})\end{array}$ & $\begin{array}{l}\mathrm{CO}_{2} \\
(\mu \mathrm{M})\end{array}$ & $\begin{array}{l}\mathrm{HCO}_{3}^{-} \\
(\mu \mathrm{M})\end{array}$ & $\begin{array}{l}\mathrm{CO}_{3}^{2-} \\
(\mu \mathrm{M})\end{array}$ & $\begin{array}{l}\text { DIC } \\
(\mathrm{uM})\end{array}$ & $\begin{array}{l}\delta^{13} \mathrm{C}-\mathrm{DIC} \\
(\% \circ \mathrm{VPDB})\end{array}$ & $\begin{array}{l}\delta^{13} \mathrm{C}^{-\mathrm{CO}_{2}} \\
(\% \circ \mathrm{VPDB})\end{array}$ & $\begin{array}{l}\text { DOC } \\
(\mu \mathrm{M})\end{array}$ & $\begin{array}{l}\mathrm{SUVA}_{254} \\
\left(\mathrm{~L} \mathrm{mgC}^{-1} \mathrm{~m}^{-1}\right)\end{array}$ & $\begin{array}{l}\mathrm{TSS} \\
\left(\mathrm{mgL}^{-1}\right)\end{array}$ & $\begin{array}{l}\text { Area } \\
\left(\mathrm{km}^{2}\right)\end{array}$ & $\begin{array}{l}\text { RTS } \\
\text { (\% area) }\end{array}$ \\
\hline \multirow{8}{*}{ 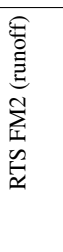 } & 1 & 7.72 & 1370 & 1046 & 43 & 1510 & 5.2 & 1559 & - & -12.1 & 758 & 1.85 & - & - & - \\
\hline & 2 & 7.51 & 1816 & 1534 & 60 & 1439 & 3.5 & 1502 & - & -11.4 & - & - & - & - & - \\
\hline & 3 & 7.71 & 1920 & 914 & 37 & 1419 & 5.4 & 1462 & - & -10.3 & - & - & - & - & - \\
\hline & 4 & 7.73 & 1903 & 878 & 38 & 1391 & 5.1 & 1433 & - & -10.0 & - & - & - & - & - \\
\hline & 5 & 7.80 & 1986 & 742 & 33 & 1386 & 5.8 & 1424 & - & -11.2 & - & - & - & - & - \\
\hline & $5^{\dagger}$ & 7.82 & 1653 & 691 & 29 & 1450 & 7.1 & 1487 & -1.0 & -11.6 & 726 & 1.84 & 15805 & - & - \\
\hline & Mean & 7.69 & 1799 & 1023 & 42 & 1429 & 5.01 & 1476 & - & -11.0 & 758 & 1.85 & - & - & - \\
\hline & SE & 0.0 & 111 & 137 & 5 & 23 & 0.39 & 25 & & 0.4 & 152 & 0.37 & & & \\
\hline \multirow{6}{*}{ 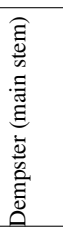 } & $1^{*}$ & 5.82 & 52 & 2467 & 124 & 115 & 0.0 & 239 & -15.0 & -21.6 & 960 & 3.66 & 5 & 2 & 0.00 \\
\hline & 2 & 7.55 & 958 & 686 & 35 & 1321 & 4.8 & 1361 & -4.2 & -16.0 & 790 & 2.53 & 11795 & 16 & 3.18 \\
\hline & 3 & 7.54 & 655 & 656 & 31 & 1073 & 3.6 & 1107 & -5.3 & -15.6 & 823 & 2.93 & 9165 & 24 & 2.18 \\
\hline & 4 & 7.35 & 416 & 600 & 30 & 946 & 2.9 & 978 & -5.7 & -18.5 & 1156 & 3.28 & 2797 & 57 & 1.19 \\
\hline & Mean & 7.07 & 520 & 1102 & 55 & 864 & 2.8 & 921 & -7.5 & -17.9 & 933 & 3.10 & 5940 & 25 & 1.64 \\
\hline & SE & 0.42 & 191 & 455 & 23 & 261 & 1.0 & 241 & 2.5 & 1.4 & 83 & 0.24 & 2735 & 12 & 0.68 \\
\hline \multirow{5}{*}{ 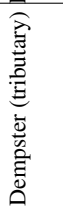 } & $2^{*}$ & 7.56 & 390 & 836 & 50 & 1233 & 2.8 & 1286 & -10.5 & -21.3 & 1053 & 3.46 & 26 & 2 & 0.00 \\
\hline & 3 & 7.32 & 171 & 478 & 23 & 561 & 1.3 & 586 & -7.2 & -18.1 & 1241 & 3.65 & 985 & 11 & 1.47 \\
\hline & 4 & 7.30 & 236 & 552 & 27 & 697 & 1.7 & 726 & -8.0 & -16.5 & 922 & 3.61 & 223 & 168 & 0.40 \\
\hline & Mean & 7.39 & 266 & 622 & 34 & 830 & 1.9 & 866 & -8.6 & -18.7 & 1072 & 3.57 & 411 & 61 & 0.62 \\
\hline & SE & 0.08 & 65 & 109 & 8 & 205 & 0.4 & 214 & 1.0 & 1.4 & 93 & 0.06 & 292 & 54 & 0.44 \\
\hline \multirow{10}{*}{ 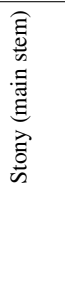 } & $1^{*}$ & 5.66 & 406 & 543 & 33 & 33 & 0.0 & 65 & -11.6 & -13.8 & 102 & 1.29 & 3 & 83 & 0.00 \\
\hline & 2 & 6.37 & 396 & 448 & 25 & 69 & 0.0 & 94 & -8.0 & -15.1 & 124 & 1.58 & 920 & 136 & 0.01 \\
\hline & 3 & 7.01 & 334 & 473 & 27 & 112 & 0.0 & 139 & -6.9 & -15.3 & 202 & 2.16 & 799 & 176 & 0.27 \\
\hline & 4 & 6.69 & 283 & 444 & 25 & 248 & 0.2 & 273 & -8.9 & -17.6 & 306 & 2.77 & 462 & 479 & 0.39 \\
\hline & 5 & 7.20 & 279 & 482 & 27 & 325 & 0.4 & 353 & -8.4 & -17.6 & 364 & 3.09 & 507 & 490 & 0.38 \\
\hline & 6 & 7.33 & 290 & 461 & 25 & 382 & 0.5 & 408 & -7.8 & -18.1 & 385 & 3.01 & 665 & 626 & 0.33 \\
\hline & 7 & 7.30 & 293 & 461 & 25 & 409 & 0.6 & 435 & -8.1 & -18.1 & 390 & 2.99 & 761 & 689 & 0.32 \\
\hline & 8 & 7.30 & 279 & 519 & 27 & 461 & 0.7 & 489 & -7.8 & -18.1 & 551 & 3.19 & 1073 & 995 & 0.36 \\
\hline & Mean & 6.86 & 320 & 479 & 27 & 255 & 0.3 & 282 & -8.4 & -16.7 & 303 & 2.51 & 649 & 459 & 0.26 \\
\hline & SE & 0.21 & 19 & 12 & 1 & 59 & 0.1 & 58 & 0.5 & 0.6 & 54 & 0.26 & 117 & 111 & 0.06 \\
\hline \multirow{9}{*}{ 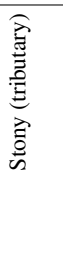 } & $1^{*}$ & 5.00 & 524 & 451 & 25 & 1 & 0.0 & 26 & -15.6 & -12.3 & 101 & 0.73 & 5 & 26 & 0.00 \\
\hline & 2 & 6.71 & 226 & 501 & 28 & 449 & 0.7 & 478 & -5.0 & -15.9 & 437 & 2.22 & 39568 & 7 & 3.50 \\
\hline & 3 & 7.11 & 148 & 448 & 26 & 338 & 0.4 & 365 & -9.3 & -18.0 & 458 & 3.12 & 10 & 59 & 0.16 \\
\hline & 4 & 6.53 & 245 & 572 & 32 & 375 & 0.4 & 407 & -8.5 & -19.4 & 550 & 3.31 & 704 & 194 & 0.67 \\
\hline & 5 & 7.00 & 479 & 494 & 26 & 601 & 1.3 & 628 & -7.0 & -18.0 & 596 & 2.88 & 1270 & 104 & 0.13 \\
\hline & 6 & 7.37 & 260 & 498 & 27 & 633 & 1.4 & 661 & -8.0 & -18.3 & 1142 & 3.34 & 1936 & 38 & 0.20 \\
\hline & 7 & 7.32 & 230 & 475 & 26 & 570 & 1.2 & 597 & -10.7 & -18.0 & 1078 & 3.56 & 1258 & 227 & 0.60 \\
\hline & Mean & 6.72 & 302 & 491 & 27 & 424 & 0.8 & 452 & -9.1 & -17.1 & 623 & 2.74 & 6393 & 94 & 0.75 \\
\hline & SE & 0.31 & 53 & 16 & 1 & 82 & 0.2 & 83 & 1.3 & 0.9 & 140 & 0.37 & 5536 & 32 & 0.47 \\
\hline
\end{tabular}

* Not RTS-affected. ${ }^{\dagger} 30$ July 2017 .

\subsection{Stable isotopic composition of carbon in DIC and $\mathrm{CO}_{2}$}

$\delta^{13} \mathrm{C}$-DIC values were highest in the RTS FM2 runoff $(-1.0 \%)$ and lower, on average, along the main stem of Dempster Creek $(-7.5 \% \circ \pm 2.5 \%$ ) and Stony Creek $(-8.4 \% \circ \pm 0.5 \%$ o). In the undisturbed headwaters of Dempster Creek and Stony Creek, relatively negative $\delta^{13} \mathrm{C}$-DIC values $(-11.6 \%$ o to $-15.6 \%$ o reflected DIC sourced from a combination of atmospheric and biogenic (soil) $\mathrm{CO}_{2}$ (Fig. 4). In the RTS FM2 runoff, relatively ${ }^{13} \mathrm{C}$-enriched $\delta^{13} \mathrm{C}$-DIC $\left(-1.0 \%\right.$ ) aligned with $\mathrm{H}_{2} \mathrm{SO}_{4}$ carbonate weathering. $\delta^{13} \mathrm{C}$ DIC decreased from $-4.2 \%$ at the first site downstream of the RTS FM2 runoff to $-5.7 \%$ at the end of Dempster Creek. Along Stony Creek, $\delta^{13} \mathrm{C}$-DIC increased from the undisturbed headwaters $(-11.6 \%)$ to the most downstream site $\left(-7.8 \%\right.$ ).$\delta^{13} \mathrm{C}$-DIC signals of $\mathrm{H}_{2} \mathrm{SO}_{4}$ carbonate weathering diminished slightly downstream along the Dempster Creek transect and intensified along Stony Creek (Fig. 4)

Similar to $\delta^{13} \mathrm{C}$-DIC, $\delta^{13} \mathrm{C}^{-\mathrm{CO}_{2}}$ values were higher in the RTS FM2 runoff $(-11.0 \% \circ \pm 0.4 \%$ o $)$ than along the main stem of Dempster Creek $(-17.9 \% \circ \pm 1.4 \% o)$ and Stony Creek (-16.7\%o $\pm 0.6 \%$; Fig. 5). $\delta^{13} \mathrm{C}^{-\mathrm{CO}_{2}}$ values were relatively low in the undisturbed headwaters of Dempster Creek $(-21.6 \%)$ and intermediate in the headwaters of Stony Creek $(-13.8 \%$; Fig. 5). Along the RTS FM2 runoff transect, $\delta^{13} \mathrm{C}-\mathrm{CO}_{2}$ values increased from sites 1 to $4(-12.1 \%$ o to $-10.0 \%$ o and decreased at site $5(-11.2 \%$ ). Along the RTS-affected reach of Dempster Creek, $\delta^{13} \mathrm{C}-\mathrm{CO}_{2}$ values decreased from $-16.0 \%$ o to $-18.5 \%$ in conjunction with inputs from non-RTS-affected tributaries having relatively low $\delta^{13} \mathrm{C}-\mathrm{CO}_{2}(-18.7 \% \circ \pm 1.4 \%)$ that was more similar to 


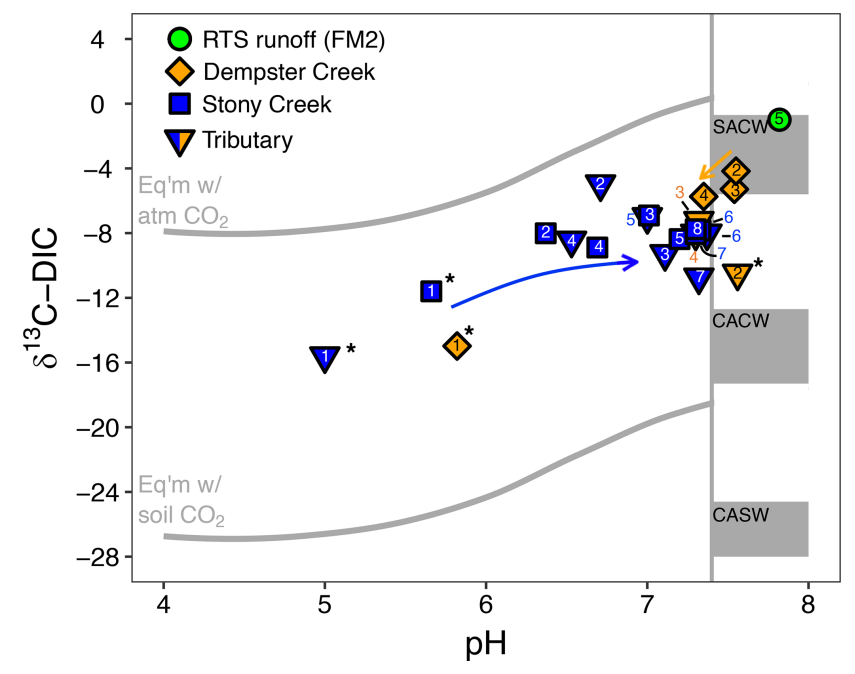

Figure 4. The $\mathrm{pH}$ and composition of dissolved inorganic carbon stable isotopes $\left(\delta^{13} \mathrm{C}\right.$-DIC) in streams. The upper and lower reference lines depict theoretical end-members for equilibrium reactions (mixing with atmospheric and biotic $\mathrm{CO}_{2}$, respectively). Gray boxes span theoretical end-member values for kinetically controlled mineral weathering reactions (SACW: $\mathrm{H}_{2} \mathrm{SO}_{4}$ carbonate weathering; CACW: $\mathrm{H}_{2} \mathrm{CO}_{3}$ carbonate weathering; CASW: $\mathrm{H}_{2} \mathrm{CO}_{3}$ silicate weathering; see Sect. 2.4 for derivation of end-members). The vertical line corresponds to the $\mathrm{pH}$ at which $\geq 90 \%$ of DIC is $\mathrm{HCO}_{3}^{-}$for the mean observed stream water temperature $\left(11.7^{\circ} \mathrm{C}\right)$. At $\mathrm{pH}<7.4, \delta^{13} \mathrm{C}$-DIC values primarily reflect equilibrium (rather than kinetic) controls on DIC cycling. Arrows reflect increasing downstream distance from the headwaters in Stony Creek and from the first retrogressive thaw slump (RTS)-affected site in Dempster Creek. Site numbers given within symbols (Table A1). * Not RTSaffected.

values from soil-respired $\mathrm{CO}_{2}$. Along Stony Creek, $\delta^{13} \mathrm{C}$ $\mathrm{CO}_{2}$ values decreased from $-13.8 \%$ to $-18.1 \%$, showing a trend opposite that of $\delta^{13} \mathrm{C}$-DIC (Fig. 5). Among sites, atmospheric $\delta^{13} \mathrm{C}-\mathrm{CO}_{2}$ values were relatively consistent $(-9.5 \% \circ \pm 0.4 \%$, mean $\pm \mathrm{SD})$.

Variance in $\delta^{13} \mathrm{C}$ of $\mathrm{CO}_{2}$ and DIC could be influenced by biotic production, $\mathrm{CO}_{2}$ conversion to $\mathrm{HCO}_{3}^{-}$, and/or mixing with atmospheric $\mathrm{CO}_{2}$. To evaluate the relative influence of these processes, we compared measured $\delta^{13} \mathrm{C}^{1} \mathrm{CO}_{2}$ for Stony Creek with theoretical values reflecting DIC controlled by speciation along the $\mathrm{pH}$ continuum (Sect. 2.4). In the undisturbed headwaters, $\delta^{13} \mathrm{C}-\mathrm{CO}_{2}$ indicated stronger influence from atmospheric $\mathrm{CO}_{2}$ (Fig. 6). Along the upper, RTSaffected reach of Stony Creek (sites $2-5$, from $\sim 5$ to $35 \mathrm{~km}$ ), the good agreement between measured and theoretical $\delta^{13} \mathrm{C}$ $\mathrm{CO}_{2}$ values reflected equilibrium fractionation $(\varepsilon=9.7 \%$ at $9{ }^{\circ} \mathrm{C}$; Mook et al., 1974) between $\mathrm{CO}_{2}$ and $\mathrm{HCO}_{3}^{-}$, indicating greater influence from DIC speciation (Fig. 6). Along the lower RTS-affected reach of the transect (sites $6-8$ ), $\delta^{13} \mathrm{C}$ $\mathrm{CO}_{2}$ values more strongly reflected biotic $\mathrm{CO}_{2}$ production, with potential effects from degassing and/or $\mathrm{CO}_{2}$ conver-

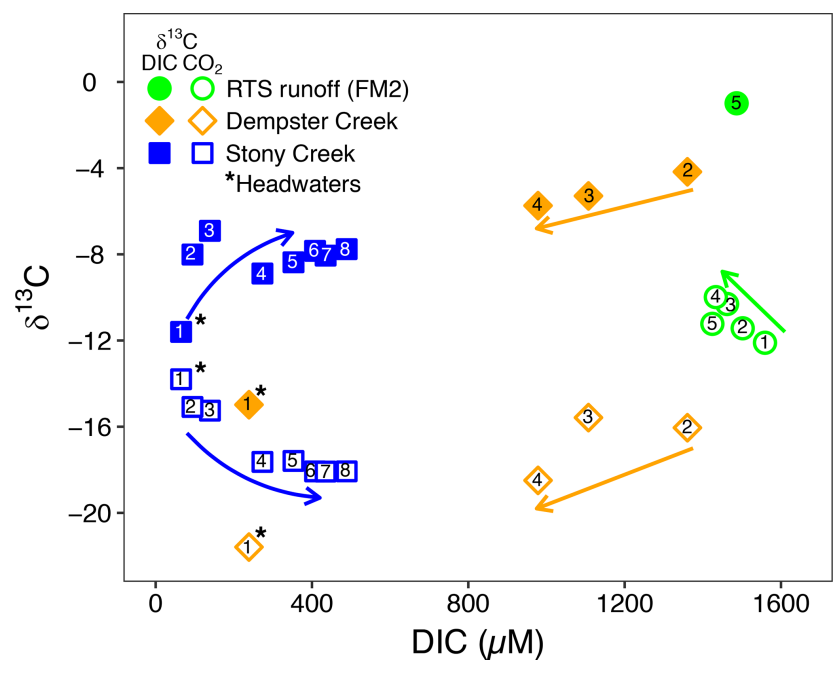

Figure 5. The composition of DIC and $\mathrm{CO}_{2}$ stable isotopes at varying DIC concentrations along the Dempster Creek and Stony Creek main stems and in the rill runoff of retrogressive thaw slump (RTS) FM2. Arrows reflect increasing downstream distance from headwaters in Stony Creek, from the first RTS-affected site in Dempster Creek, and from the start of the FM2 runoff transect. Site numbers given within symbols (Table A1). ${ }^{*}$ Site in headwaters and not affected by RTSs.

sion to $\mathrm{HCO}_{3}^{-}$. These trends in $\delta^{13} \mathrm{C}_{-}-\mathrm{CO}_{2}$ values along Stony Creek show a downstream change in the processes influencing DIC source, which may be related to inputs of weathering solutes and organic matter from RTS-affected tributaries.

\subsection{Stony Creek tributary carbonate alkalinity yields and watershed characteristics}

Carbonate alkalinity yields in RTS-affected tributaries of Stony Creek $\left(1558 \pm 1135 \mu \mathrm{mol} \mathrm{m}{ }^{-2} \mathrm{~d}^{-1}\right.$, mean $\left.\pm \mathrm{SD}\right)$ were 3 orders of magnitude higher than in the non-RTS-affected headwaters $\left(1.8 \mu \mathrm{mol} \mathrm{m}^{-2} \mathrm{~d}^{-1}\right.$; Table 3$)$. Consecutive downstream tributary watersheds exhibited no clear trends in the number of RTSs, the area disturbed by RTSs, terrain roughness, or EVI. In the Stony Creek headwater tributary, which had no active RTSs, terrain roughness $(16.2 \mathrm{~m})$ and vegetation productivity $(\mathrm{EVI}=0.28)$ were higher than in the other six tributary watersheds $(4.3 \pm 1.3 \mathrm{~m}$ and $0.46 \pm 0.01$, mean $\pm \mathrm{SD}$, respectively). In the other tributary watersheds, the number of active RTSs reached $50(15 \pm 17$, mean \pm SD), and RTS disturbance area reached $3.5 \%(0.91 \% \pm 1.29 \%$, mean \pm SD; Table 3).

To elucidate landscape controls on carbonate alkalinity export in Stony Creek tributary watersheds, we paired geospatial data for active RTSs, terrain roughness, and vegetation productivity with estimates of carbonate alkalinity and water yields in a multiple linear regression model (Sect. 2.7). Water yield and the area of RTS disturbance were retained during automated covariate selection for the final model $\left(F_{2,4}=63\right.$, 
Table 3. Characteristics of Stony Creek tributary watersheds (upper panel) and results from the multiple linear regression model (lower panel). The Stony Creek watershed contained 109 retrogressive thaw slumps (RTSs), 92 of which were in the major tributaries of the Stony Creek main stem. TR: terrain roughness. EVI: enhanced vegetation index. Values were used in the multiple linear regression model to determine the drivers of $\mathrm{HCO}_{3}^{-}$yields in Stony Creek tributary watersheds. Model results are shown in the lower panel. Covariates eliminated during model selection $\left(\mathrm{RTS}_{n}, \mathrm{TR}, \mathrm{EVI}\right)$ are not reflected in the lower panel or final model: $\ln \mathrm{HCO}_{3}^{-}$yield $=1.04 \ln$ water yield $+0.35 \ln \mathrm{RTS}$ area +8.76 .

\begin{tabular}{lrrrrrr}
\hline Tributary & $\begin{array}{l}\mathrm{HCO}_{3}^{-} \text {yield } \\
\left(\mu \mathrm{Mm}^{-2} \mathrm{~d}^{-1}\right)\end{array}$ & $\begin{array}{l}\text { Water yield } \\
\left(\mathrm{cm} \mathrm{d}^{-1}\right)\end{array}$ & $\begin{array}{l}\text { RTSs } \\
(\% \text { area })\end{array}$ & $\begin{array}{l}\text { RTSs } \\
(n)\end{array}$ & $\begin{array}{l}\text { Mean } \\
\text { TR }(\mathrm{m})\end{array}$ & $\begin{array}{l}\text { Mean } \\
\text { EVI }\end{array}$ \\
\hline 1 & 2 & 0.20 & 0.00 & 0 & 16.2 & 0.28 \\
2 & 2819 & 0.61 & 3.50 & 6 & 3.4 & 0.48 \\
3 & 1047 & 0.18 & 0.16 & 3 & 6.7 & 0.45 \\
4 & 227 & 0.04 & 0.67 & 50 & 4.5 & 0.45 \\
5 & 1378 & 0.12 & 0.31 & 11 & 4.7 & 0.46 \\
6 & 3056 & 0.28 & 0.20 & 8 & 2.7 & 0.47 \\
7 & 821 & 0.07 & 0.60 & 14 & 3.6 & 0.45 \\
\hline Covariate & Estimate & $t$ & $p$ & & & \\
\hline ln water yield & 1.04 & 3.6 & 0.02 & & & \\
ln RTS area & 0.35 & 10.5 & $<0.001$ & & & \\
\hline
\end{tabular}

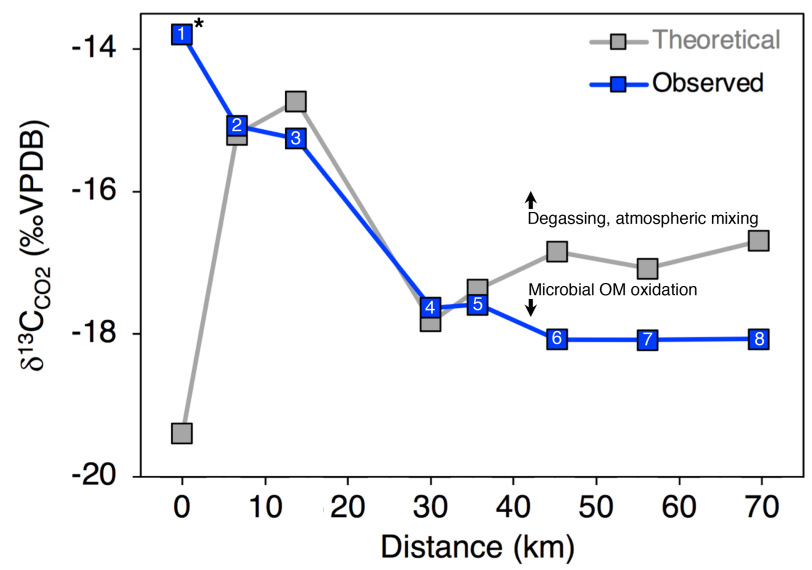

Figure 6. Observed and expected $\delta^{13} \mathrm{C}-\mathrm{CO}_{2}$ values along the Stony Creek main stem. Theoretical $\delta^{13} \mathrm{C}-\mathrm{CO}_{2}$ values were calculated as detailed in Sect. 2.6 and reflect changes in $\mathrm{CO}_{2}$ due to DIC speciation (i.e., $\mathrm{H}_{2} \mathrm{CO}_{3} \rightleftharpoons \mathrm{H}^{+}+\mathrm{HCO}_{3}^{-}$; Eq. 8). Deviation from theoretical $\delta^{13} \mathrm{C}-\mathrm{CO}_{2}$ values by observed values thus indicates isotopic effects from degassing and/or microbial oxidation of organic matter $(\mathrm{OM})$, as indicated by the arrows. Site numbers given within symbols (Table A1). * Site was not affected by retrogressive thaw slumps.

$p<0.001, R^{2}=0.95$ ). In addition to the expected relationship between water yield and carbonate alkalinity yield, RTS disturbance area was a clear, significant predictor of carbonate alkalinity yield and formed a stronger relationship with alkalinity than did water yield (Table 3 ).

\section{Discussion}

\subsection{Rapid carbon cycling in fluvial network headwaters}

Within undisturbed headwaters and RTS runoff on the Peel Plateau, rapid carbon cycling enhanced fluvial $\mathrm{CO}_{2}$ efflux to the atmosphere. In undisturbed headwaters, ${ }^{13} \mathrm{C}_{-} \mathrm{CO}_{2}$ values indicate inputs of primarily biogenic $\mathrm{CO}_{2}$ from soil respiration into Dempster Creek. In the Stony Creek headwaters, intermediate $\delta^{13} \mathrm{C}_{-}-\mathrm{CO}_{2}$ and $p \mathrm{CO}_{2}$ saturation suggested influence from exchange with atmospheric $\mathrm{CO}_{2}$ and from some biogenic $\mathrm{CO}_{2}$. In the undisturbed Dempster Creek headwaters, a $70 \%$ decrease in $p \mathrm{CO}_{2}$ within several kilometers downstream likely reflected degassing and diminishing inputs of respired $\mathrm{CO}_{2}$ from soils to streams relative to headwaters (Hutchins et al., 2019). These trends resemble headwater streams elsewhere in that hydrologic inputs of respired $\mathrm{CO}_{2}$ from riparian soils can drive $\mathrm{CO}_{2}$ supersaturation in fluvial network headwaters (Campeau et al., 2018; Crawford et al., 2013), which is rapidly effluxed to the atmosphere over short distances downstream (Hotchkiss et al., 2015). In contrast, trends in hydrochemistry and stable isotopes within RTS FM2 runoff demonstrate that drivers of carbon cycling within RTSs are starkly different from those in undisturbed headwaters on the Peel Plateau.

Along the RTS FM2 runoff transect, the increase in conductivity corroborates experimental evidence (Zolkos and Tank, 2020) that permafrost sediments on the Peel Plateau can rapidly weather during fluvial transport within runoff. In the upper reach of the runoff transect, near RTS FM2, the decrease in $\mathrm{HCO}_{3}^{-}$, increase in $\mathrm{CO}_{2}$, and relatively enriched $\delta^{13} \mathrm{C}_{-}-\mathrm{CO}_{2}$ (Fig. 5) indicate rapid production of geogenic $\mathrm{CO}_{2}$ via $\mathrm{H}_{2} \mathrm{SO}_{4}$ carbonate weathering (Eq. 7) and carbonate equilibrium reactions (Eq. 8). In Yedoma terrains in 
Siberia and Alaska, where mineral soils are relatively more organic-rich, thermokarst is associated with production of biogenic $\mathrm{CO}_{2}$ (Drake et al., 2018b). While respiration likely produced some $\mathrm{CO}_{2}$ in RTS FM2 runoff (Littlefair et al., 2017), observed $\delta^{13} \mathrm{C}-\mathrm{CO}_{2}(-11 \%)$ more strongly reflected $\mathrm{H}_{2} \mathrm{SO}_{4}$ weathering of regional carbonate bedrock $(-0.7 \%$ o to $-5.6 \%$; Hitchon and Krouse, 1972) when accounting for isotopic fractionation of $\sim 8 \%$ between carbonate and $\mathrm{CO}_{2}$ at the temperature of FM2 runoff $\left(18^{\circ} \mathrm{C}\right.$; Clark and Fritz, 1997). Along the lower reach of the FM2 runoff transect, the increase in $\delta^{13} \mathrm{C}-\mathrm{CO}_{2}$ aligned with the preferential loss of ${ }^{12} \mathrm{C}$ in the $\mathrm{CO}_{2}$ phase via DIC fractionation and degassing (Doctor et al., 2008; Drake et al., 2018b; Kendall et al., 2014). ${ }^{13} \mathrm{C}$ enrichment of the $\mathrm{CO}_{2}$ pool by methanogenesis (Campeau et al., 2018), photosynthesis (Descolas-Gros and Fontungne, 1990), and/or calcite precipitation (Turner, 1982) was unlikely as $\mathrm{CH}_{4}$ in FM2 runoff was relatively low $\left(p \mathrm{CH}_{4}=3.6 \pm 1.9 \mu \mathrm{atm}\right.$, mean $\left.\pm \mathrm{SD}, n=6\right)$, the high turbidity of FM2 runoff likely inhibited photosynthesis (Levenstein et al., 2018), and calcite was below saturation ( $\mathrm{SI}=-0.79)$. These trends demonstrate that weathering of sediments during fluvial transport within RTS runoff can result in rapid $\mathrm{CO}_{2}$ production and efflux to the atmosphere, in agreement with recent estimates of high rates of $\mathrm{CO}_{2}$ efflux within RTS runoff (Zolkos et al., 2019).

High rates of weathering within RTS FM2 runoff aligns with observations of substantial solute production via the exposure and weathering of carbonate flour in glacial foreground environments (Anderson, 2007; Sharp et al., 1995; St. Pierre et al., 2019). Because minerals exposed by deeper RTSs are generally reactive, and sediment concentrations increased by 3 orders of magnitude between the undisturbed Dempster Creek headwaters and the first RTS-affected site, we reasoned that $\mathrm{H}_{2} \mathrm{CO}_{3}$ weathering of these sediments during fluvial transport would measurably influence $p \mathrm{CO}_{2}$ along Dempster Creek (Eq. 1; St. Pierre et al., 2019; Striegl et al., 2007). Although $p \mathrm{CO}_{2}$ decreased along the RTS-affected reach of the Dempster Creek transect (sites 2-4; Fig. 2b), coincident decreases in conductivity, $\mathrm{HCO}_{3}^{-}$, and $\mathrm{pH}$ (Table 2, Figs. 2a and 4) suggest that degassing and dilution associated with inputs from non-RTS-affected tributaries had stronger effects on $p \mathrm{CO}_{2}$ than did $\mathrm{H}_{2} \mathrm{CO}_{3}$ carbonate weathering, even at the relatively short scale of this $14 \mathrm{~km}$ transect. From a carbon cycling perspective, biogeochemically reactive mineral substrate appears to be rapidly transformed in headwaters on the Peel Plateau; geogenic $\mathrm{CO}_{2}$ production is relegated to within RTSs; and more stable weathering products, including alkalinity, are exported downstream.

\subsection{RTS activity in headwaters amplifies carbonate alkalinity production and accumulation across scales}

Similar to $\mathrm{CO}_{2}$, alkalinity production on the Peel Plateau was strongly coupled to primarily $\mathrm{H}_{2} \mathrm{SO}_{4}$ carbonate weathering mediated by RTS activity. This was reflected by a modest decrease in $\mathrm{HCO}_{3}^{-}$along Dempster Creek in tandem with decreasing RTS disturbance area (from $3.2 \%$ to $1.2 \%$ ) and some dilution by inputs from non-RTS-affected tributaries. Multiple linear regression results further indicated that RTS activity was a primary terrain control on carbonate alkalinity yields. In the Stony Creek headwaters, low carbonate alkalinity yield relative to water yield suggested that $\mathrm{HCO}_{3}^{-}$ export was limited by carbonate availability rather than by water. In RTS-affected tributaries, higher carbonate alkalinity yields relative to water yields aligned with the model results indicating that RTS activity increases carbonate weathering and alkalinity export beyond what would otherwise be expected on the Peel Plateau. $\mathrm{HCO}_{3}^{-}$yields in RTS-affected tributaries were comparable to summertime $\mathrm{HCO}_{3}^{-}$yields in watersheds with carbonate rock weathering by glacial activity $\left(\sim 3000 \mu \mathrm{mol} \mathrm{m}{ }^{-2} \mathrm{~d}^{-1}\right.$; Lafrenière and Sharp, 2004; Striegl et al., 2007), emphasizing that unmodified sulfideand carbonate-bearing sediments in regional permafrost are highly reactive (Zolkos and Tank, 2020) and primary sources of DIC within intermediate-sized $\left(1000 \mathrm{~km}^{2}\right)$ fluvial networks. This aligns with stable sulfur isotopes in RTS runoff and near the Stony Creek outflow that strongly reflected sulfide oxidation (Zolkos et al., 2018). Unlike $\mathrm{CO}_{2}$, the increase in $\mathrm{HCO}_{3}^{-}$by orders of magnitude along Stony Creek in association with inputs from RTS-affected tributaries shows that more chemically stable (i.e., nongaseous) weathering products accumulated across scales. This aligns with previous findings that solutes and sediments from RTSs propagate through fluvial networks (Kokelj et al., 2013; Malone et al., 2013) and suggests that future intensification of RTS activity (Segal et al., 2016) will increase $\mathrm{HCO}_{3}^{-}$export to downstream environments.

\subsection{Integration of RTS effects on carbon cycling across watershed scales}

These findings enable us to develop a conceptual model of catchment chemical characteristics and how the effects of RTS activity on carbon cycling integrate across watershed scales on the Peel Plateau (Fig. 7). This model may be generalized to permafrost terrains elsewhere for testing hypotheses related to thermokarst effects on carbon cycling across the land-fresh water-ocean continuum (Tank et al., 2020).

In undisturbed headwaters on the Peel Plateau, DIC was primarily $\mathrm{CO}_{2}$, and sources of $\mathrm{CO}_{2}$ varied from relatively more atmospheric in the sparsely vegetated and mountainous Stony Creek headwaters (Fig. 7ai) to more biogenic in the tundra-taiga headwaters of Dempster Creek (Fig. 7aii). Downstream, $\mathrm{CO}_{2}$ loss and mixing of streams resulted in undisturbed headwaters having relatively modest DIC comprised of a relatively large proportion of $\mathrm{CO}_{2}$ sourced from mixing with the atmosphere and likely some inputs from soil respiration (Fig. 7aiii). Underlying the trends in $\mathrm{CO}_{2}$ concen- 


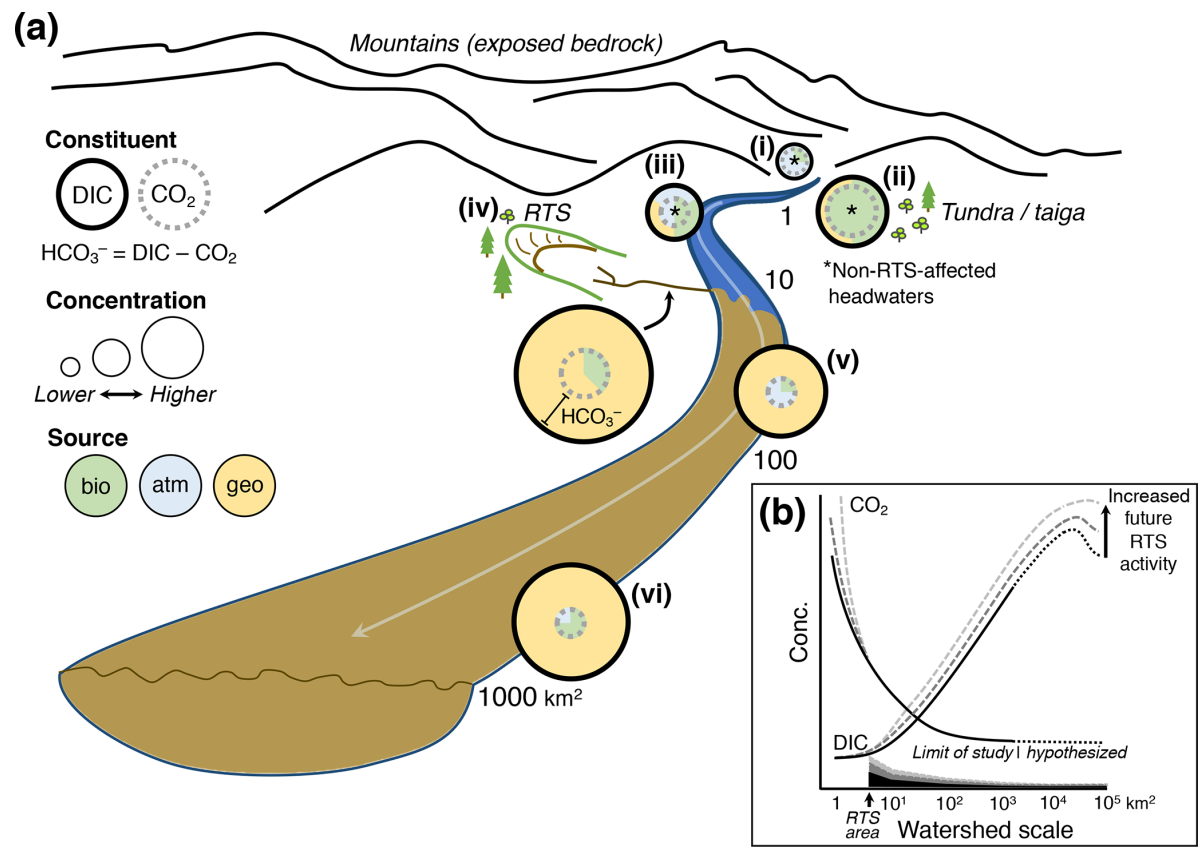

Figure 7. (a) Conceptual model of retrogressive thaw slump (RTS) activity and mineral weathering effects on carbon cycling in glaciated thermokarst terrains like the Peel Plateau. Bio: biogenic; atm: atmospheric; geo: geogenic. (b) RTS effects on $\mathrm{CO}_{2}$ and DIC $\left(\Sigma\left[\mathrm{CO}_{2}\right.\right.$, carbonate alkalinity]) observed in this study (dark solid line), projected across broader scales in the modern-day (dark dotted line), and under hypothetical future scenarios of increasing RTS activity (medium- and light-gray dashed lines). Shaded regions along $x$ axis depict relative RTS area approximated for modern-day (black) and for hypothetical future increases in RTS area (medium- and light-gray).

tration, measurements of $\delta^{13} \mathrm{C}-\mathrm{CO}_{2}$ revealed shifting sources of $\mathrm{CO}_{2}$ across scales (discussed below).

Thaw and exposure of reactive tills (Lacelle et al., 2019; Zolkos and Tank, 2020) by RTS activity in Peel Plateau headwaters (see also Kokelj et al., 2013; Malone et al., 2013) promotes mineral weathering, rapidly generating $\mathrm{CO}_{2}$, and substantial alkalinity. Alkalinity, along with large amounts of sediment (van der Sluijs et al., 2018) and organic matter (Shakil et al., 2020), are exported from RTSs into fluvial networks (Fig. 7aiv). Similar to other locations, DOC in RTS runoff on the Peel Plateau is known to be relatively biolabile (Littlefair et al., 2017), suggesting inputs from RTS FM2 to larger streams (e.g., Dempster Creek) could stimulate biotic $\mathrm{CO}_{2}$ production.

$\mathrm{CO}_{2}$ degassing is most pronounced within RTSs and in undisturbed headwaters that are strongly coupled with soil respiration, and active mineral weathering is less pronounced in midorder streams (e.g., Dempster Creek). Hence, midorder streams, which also mix with inputs from undisturbed tributaries, export $\mathrm{HCO}_{3}^{-}$downstream at a magnitude coupled to the area of RTS disturbance (Fig. 7av). Further, immediately downstream of the RTS FM2 inflow to Dempster Creek, the decrease in $\mathrm{CO}_{2}$ and shift in $\delta^{13} \mathrm{C}-\mathrm{CO}_{2}$ away from a biotic source suggest that $\mathrm{CO}_{2}$ degassing to the atmosphere was more prominent than respiration of permafrost DOC (Doctor et al., 2008; Drake et al., 2018b; Kendall et al., 2014). Thus, immediately downstream of RTSs, microbial respiration of permafrost DOC does not appear to generate substantial $\mathrm{CO}_{2}$. This may be due to lower rates of DOC mineralization than degassing and/or the protection of DOC from microbial oxidation via adsorption to RTS sediments (Gentsch et al., 2015). The latter aligns with the observed decrease in DOC concentration and increase in TSS (to $11800 \mathrm{mg} \mathrm{L}^{-1}$ ) between Dempster Creek sites 1 and 2 (Table 2, Fig. 3c; see also Littlefair et al., 2017). However, these effects may diminish farther downstream in midorder streams. Along the lower reach of Dempster Creek (sites 3-4), the decrease in $\delta^{13} \mathrm{C}-$ $\mathrm{CO}_{2}$, increase in DOC, and $\mathrm{SUVA}_{254}$ resembling terrestrialorigin DOC from tributary streams suggest that undisturbed tributary streams may deliver biogenic $\mathrm{CO}_{2}$ and/or stimulate organic matter respiration in RTS-affected streams. Thus, effects of RTS sediments on $\mathrm{CO}_{2}$ are attenuated downstream as DOC inputs increase.

Up to and likely beyond scales of $\sim 10^{3} \mathrm{~km}^{2}$ (e.g., Stony Creek), the largest scale of this study, $\mathrm{HCO}_{3}^{-}$concentrations are likely to increase significantly downstream, reflecting the export of relatively stable weathering products (see also Kokelj et al., 2013; Malone et al., 2013; Zolkos et al., 2018) and accumulation of carbonate alkalinity (Figs. 7avi, b). These effects were primarily driven by inputs of $\mathrm{HCO}_{3}^{-}$ from RTS-affected tributaries, which also increased DOC significantly along Stony Creek. Potentially owing to organic matter limitation, $\mathrm{CO}_{2}$ in the undisturbed headwaters of Stony Creek appeared to be driven by relatively faster 
carbonate equilibrium reactions (Eq. 8; Stumm and Morgan, 1996). In contrast, along the lower RTS-affected reach of Stony Creek as $\mathrm{HCO}_{3}^{-}$and DOC increased and $\mathrm{pH}$ stabilized, $\delta^{13} \mathrm{C}-\mathrm{CO}_{2}$ measurements suggest that respiration of organic matter from RTS-affected tributaries contributed to $\mathrm{CO}_{2}$ oversaturation (Fig. 6). In higher-order streams within RTS-affected fluvial networks, biotic $\mathrm{CO}_{2}$ production may increase together with $\mathrm{HCO}_{3}^{-}$concentrations. This trend was not evident in $\delta^{13} \mathrm{C}$-DIC, which primarily reflected inputs of geogenic DIC from RTS-affected tributaries. Thus, sources of $\mathrm{CO}_{2}$ may shift across scales in RTS-affected fluvial networks, and measurements of $\delta^{13} \mathrm{C}_{-} \mathrm{CO}_{2}$ highlight a decoupling between the drivers of $\mathrm{CO}_{2}$ and $\mathrm{HCO}_{3}^{-}$at larger scales (Horgby et al., 2019; Hutchins et al., 2020). A stronger signal of biogenic $\mathrm{CO}_{2}$ production in larger streams than in permafrost thaw streams within thermokarst, as we observed, is opposite to common trends in Yedoma terrains (Drake et al., 2018b) and may partly reflect limitation of organic substrate in Stony Creek headwaters that is relieved by RTS inputs farther downstream (Shakil et al., 2020). Underlying these trends, RTS disturbance area increased along the Stony Creek transect, from $0 \%$ in the undisturbed headwaters to $0.36 \%$ in the tributary watersheds (sites 4-8). Despite RTS activity occupying a small proportion of the landscape, carbonate alkalinity propagated through fluvial networks. These findings directly link intensifying RTS activity on the Peel Plateau (Segal et al., 2016) with signals of increasing weathering and carbonate alkalinity export in the broader Peel and Mackenzie River watersheds (Tank et al., 2016; Zolkos et al., 2018).

\subsection{Implications for carbon cycling in northern permafrost regions}

Permafrost terrains susceptible to hillslope thermokarst like RTSs occur within and outside of former glacial limits across the circumpolar north (Olefeldt et al., 2016; Zolkos et al., 2018), and variability in geology, glacial activity, climate, and ecosystem history cause permafrost mineral composition to vary between regions. The degree to which carbonate weathering is coupled with sulfide oxidation will determine if mineral weathering is a $\mathrm{CO}_{2}$ sink (Eq. 1) or source (Eqs. 3 and 7) over the coming millennia (Zolkos et al., 2018). Where thermokarst releases inorganic substrate with limited prior modification - as in larger RTSs on the Peel Plateau (Lacelle et al., 2019; Zolkos and Tank, 2020) - carbon cycling can be expected to be rapid and driven by inorganic processes and strengthen abiotic components of the permafrost carbon-climate feedback (Schuur et al., 2015). Current dynamic-numerical biogeochemical models for the Mackenzie River basin suggest that the ubiquity of sulfide minerals reduces weathering consumption of atmospheric $\mathrm{CO}_{2}$ by half (Beaulieu et al., 2012). These models do not account for enhanced $\mathrm{H}_{2} \mathrm{SO}_{4}$ carbonate weathering associated with RTS activity, which our results show is significantly and positively correlated with alkalinity production and export across watershed scales. Further, climate feedbacks associated with RTS activity appear to be scale-dependent. RTSs rapidly generate $\mathrm{CO}_{2}$, but its outgassing occurs mostly within runoff and comprises a small proportion of watershedscale fluvial $\mathrm{CO}_{2}$ efflux (Zolkos et al., 2019). Carbonate alkalinity generated within RTSs represents a much larger positive feedback to climate change, albeit over geological timescales, via carbonate precipitation reactions within the marine carbon cycle (Calmels et al., 2007). Future intensification of RTS activity (Segal et al., 2016) can thus be expected to increase geogenic $\mathrm{CO}_{2}$ production within headwaters (see also Zolkos et al., 2019) and carbonate alkalinity export across scales (Fig. 7b; Tank et al., 2016). Cross-scale watershed investigations will help to understand these effects across terrains with varying lithologies and permafrost composition and the implications of hillslope thermokarst for climate feedbacks.

\section{Conclusions}

Climate-driven renewal of geomorphic activity across permafrost-preserved glaciogenic terrain and associated carbonate weathering in the western Canadian Arctic is amplifying aquatic carbon export across scales, despite RTSs disturbing only a fractional proportion of the landscape. Primary consequences include geogenic $\mathrm{CO}_{2}$ production that is rapid and localized to RTSs and augments soil-respired $\mathrm{CO}_{2}$ efflux from undisturbed headwater streams. Significant carbonate alkalinity production and export from RTSs project through fluvial networks and likely to Arctic coastal marine environments, forecasting stronger land-fresh waterocean linkages (Tank et al., 2016) as RTS activity intensifies in glacial margin landscapes across northwestern Canada (Kokelj et al., 2017a). Legacy effects of RTSs on carbon cycling can be expected to persist for millennia, indicating a need for the integration of dynamic-numerical biogeochemical models (Beaulieu et al., 2012) into predictions of weathering-carbon-climate feedbacks (Zolkos et al., 2018) among northern thermokarst terrains (Turetsky et al., 2020). 


\section{Appendix A}

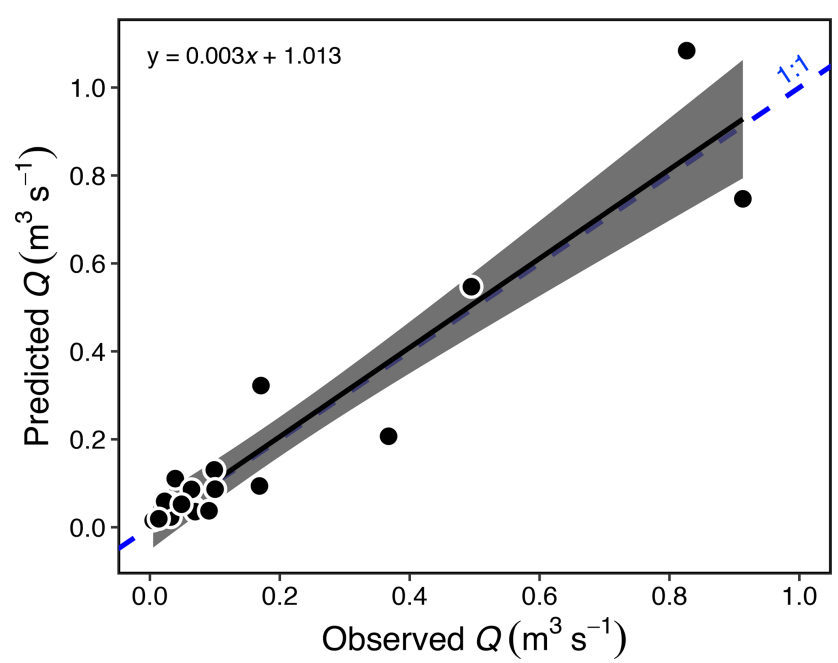

Figure A1. Estimated vs. measured discharge $\left(Q ; p<0.001, R^{2}=0.89, F_{1,18}=150\right)$ for 20 streams in the Stony Creek watershed. The gray band represents the $95 \%$ confidence interval shown around the regression. Estimates were made using measurements of stream width, $Q$, and a hydraulic-geometry model (Gordon et al., 2004; see Sect. 2.6). The model (Eq. 1) was used to estimate $Q$ in the Stony Creek tributaries.

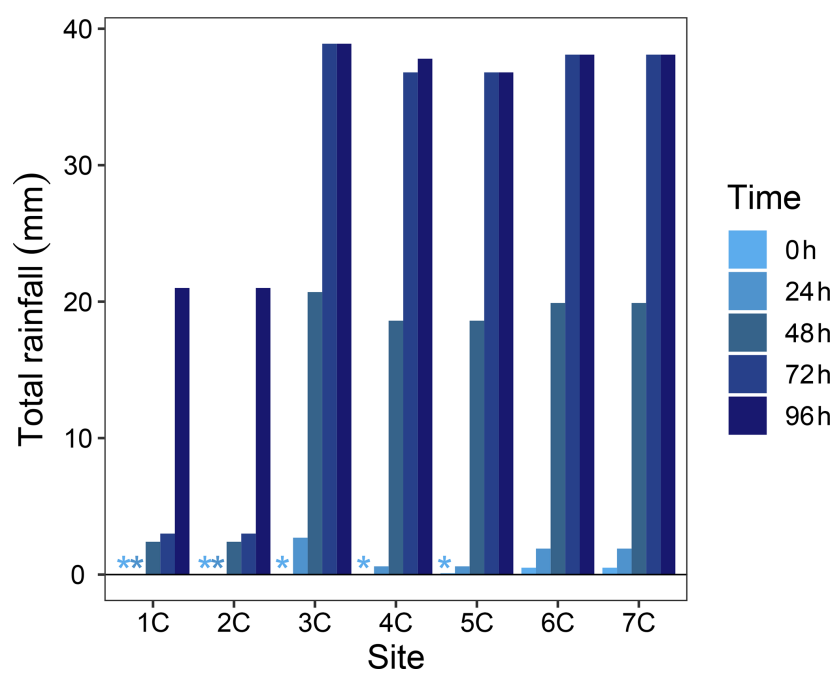

Figure A2. Total rainfall in $24 \mathrm{~h}$ increments preceding the sampling of each Stony Creek tributary. Rainfall data were obtained from a Government of Northwest Territories weather station on the Peel Plateau located near the RTS FM2. Locations of tributary sampling sites and the weather station are shown in Fig. $1 .{ }^{*}$ Indicates no rainfall in the $24 \mathrm{~h}$ window. 
Table A1. Sampling site characteristics. Retrogressive thaw slump (RTS) FM2 runoff was a tributary to Dempster Creek (confluence upstream of site 2), and Dempster Creek was a tributary to Stony Creek (confluence upstream of site 8). Coordinates reported in decimal degrees (DDs).

\begin{tabular}{|c|c|c|c|c|c|c|c|c|}
\hline Creek & Site & Type & $\begin{array}{r}\text { Latitude } \\
\text { (DDs) }\end{array}$ & $\begin{array}{r}\text { Longitude } \\
\text { (DDs) }\end{array}$ & Sampling date & $\begin{array}{r}\text { Distance } \\
(\mathrm{km})\end{array}$ & $\begin{array}{r}\text { Elevation } \\
(\mathrm{m})\end{array}$ & $\begin{array}{r}\text { Stream order } \\
\text { (Strahler) }\end{array}$ \\
\hline RTS FM2 & 1 & Runoff & 67.25639 & -135.23422 & $31 \mathrm{Jul} 2017$ & 0 & - & 1 \\
\hline RTS FM2 & 2 & Runoff & 67.25726 & -135.23756 & $31 \mathrm{Jul} 2017$ & 0.22 & - & 1 \\
\hline RTS FM2 & 3 & Runoff & 67.25813 & -135.23700 & $31 \mathrm{Jul} 2017$ & 0.33 & - & 1 \\
\hline RTS FM2 & 4 & Runoff & 67.25894 & -135.23636 & $31 \mathrm{Jul} 2017$ & 0.44 & - & 1 \\
\hline RTS FM2 & 5 & Runoff & 67.25986 & -135.23595 & $31 \mathrm{Jul} 2017$ & 0.55 & - & 1 \\
\hline RTS FM2 & 5 & Runoff & 67.25981 & -135.23587 & $30 \mathrm{Jul} 2017$ & - & 271 & 1 \\
\hline Dempster & $1^{*}$ & Main stem & 67.25181 & -135.29456 & $31 \mathrm{Jul} 2017$ & 0 & 407 & 3 \\
\hline Dempster & 2 & Main stem & 67.27364 & -135.20409 & $29 \mathrm{Jul} 2017$ & 5.6 & 194 & 4 \\
\hline Dempster & 3 & Main stem & 67.29500 & -135.17570 & 27 Jul 2017 & 8.9 & 132 & 4 \\
\hline Dempster & 4 & Main stem & 67.32336 & -135.14133 & 27 Jul 2017 & 13.5 & 67 & 4 \\
\hline Dempster & $2^{*}$ & Tributary & 67.27364 & -135.20367 & $29 \mathrm{Jul} 2017$ & - & - & 2 \\
\hline Dempster & 3 & Tributary & 67.29497 & -135.17538 & 27 Jul 2017 & - & - & 3 \\
\hline Dempster & 4 & Tributary & 67.32414 & -135.14252 & 27 Jul 2017 & - & - & 4 \\
\hline Stony & $1^{*}$ & Main stem & 67.30280 & -136.00468 & 27 Jul 2017 & 0 & 575 & 4 \\
\hline Stony & 2 & Main stem & 67.33878 & -135.90912 & $27 \mathrm{Jul} 2017$ & 6.6 & 474 & 4 \\
\hline Stony & 3 & Main stem & 67.35704 & -135.78165 & $25 \mathrm{Jul} 2017$ & 13.8 & 382 & 4 \\
\hline Stony & 4 & Main stem & 67.34913 & -135.48802 & $25 \mathrm{Jul} 2017$ & 30.0 & 230 & 5 \\
\hline Stony & 5 & Main stem & 67.38380 & -135.45747 & $25 \mathrm{Jul} 2017$ & 35.7 & 184 & 6 \\
\hline Stony & 6 & Main stem & 67.34879 & -135.30302 & $25 \mathrm{Jul} 2017$ & 45.3 & 123 & 6 \\
\hline Stony & 7 & Main stem & 67.32732 & -135.12160 & $25 \mathrm{Jul} 2017$ & 56.2 & 57 & 6 \\
\hline Stony & 8 & Main stem & 67.39000 & -134.98380 & $25 \mathrm{Jul} 2017$ & 69.7 & 6 & 6 \\
\hline Stony & $1^{*}$ & Tributary & 67.30367 & -136.00421 & 27 Jul 2017 & - & - & 3 \\
\hline Stony & 2 & Tributary & 67.33933 & -135.90836 & 27 Jul 2017 & - & - & 3 \\
\hline Stony & 3 & Tributary & 67.35719 & -135.78311 & $25 \mathrm{Jul} 2017$ & - & - & 4 \\
\hline Stony & 4 & Tributary & 67.34860 & -135.48773 & $25 \mathrm{Jul} 2017$ & - & - & 5 \\
\hline Stony & 5 & Tributary & 67.38467 & -135.45607 & $25 \mathrm{Jul} 2017$ & - & - & 4 \\
\hline Stony & 6 & Tributary & 67.34882 & -135.30196 & $25 \mathrm{Jul} 2017$ & - & - & 4 \\
\hline Stony & 7 & Tributary & 67.32703 & -135.12213 & $25 \mathrm{Jul} 2017$ & - & - & 5 \\
\hline
\end{tabular}

* Not RTS-affected. 
Data availability. All data used in this study are available in the supplement.

Supplement. The supplement related to this article is available online at: https://doi.org/10.5194/bg-17-5163-2020-supplement.

Author contributions. SZ and SET designed the study with contribution from RGS and SVK. SZ led the field research, laboratory analyses, and manuscript writing. JK contributed to geospatial analyses. CEA contributed to laboratory analyses. All authors (SZ, SET, RGS, SVK, JK, CEA, DO) contributed to manuscript writing.

Competing interests. The authors declare that they have no conflict of interest.

Acknowledgements. We thank Rosemin Nathoo, Christine Firth, Dempster Collin, Abraham Snowshoe, Sarah Shakil, and Erin MacDonald for assistance in the field. This paper is NWT Geological Survey contribution no. 0131. Any use of trade, product, or firm names in this publication is for descriptive purposes only and does not imply endorsement by the US Government.

Financial support. This research has been supported by the Natural Sciences and Engineering Research Council of Canada Discovery Grant (grant no. 430696), the Natural Sciences and Engineering Research Council of Canada Northern Research Supplement (grant no. 444873), the Natural Resources Canada Polar Continental Shelf Program (grant no. 61717), the Campus Alberta Innovates Program, the Environment Canada Science Youth Horizons (grant no. GCXE16S064), the UAlberta Northern Research Award, and the Arctic Institute of North America Grant-in-Aid.

Review statement. This paper was edited by Ji-Hyung Park and reviewed by three anonymous referees.

\section{References}

Anderson, S. P.: Biogeochemistry of Glacial Landscape Systems, Annu. Rev. Earth Pl. Sc., 35(1), 375-399, https://doi.org/10.1146/annurev.earth.35.031306.140033, 2007.

Beaulieu, E., Goddéris, Y., Donnadieu, Y., Labat, D., and Roelandt, C.: High sensitivity of the continental-weathering carbon dioxide sink to future climate change, Nat. Clim. Change, J2, 346-349, https://doi.org/10.1038/nclimate1419, 2012.

Berner, R. A.: Weathering, plants, and the long-term carbon cycle, Geochim. Cosmochim. Ac., 56, 3225-3231, 1992.

Berner, R. A.: A new look at the long-term carbon cycle, GSA Today, 9, 1-6, 1999.

Biskaborn, B. K., Smith, S. L., Noetzli, J., Matthes, H., Vieira, G., Streletskiy, D. A., Schoeneich, P., Romanovsky, V. E., Lewkowicz, A. G., Abramov, A., Allard, M., Boike, J., Cable, W. L.,
Christiansen, H. H., Delaloye, R., Diekmann, B., Drozdov, D., Etzelmüller, B., Grosse, G., Guglielmin, M., Ingeman-Nielsen, T., Isaksen, K., Ishikawa, M., Johansson, M., Johannsson, H., Joo, A., Kaverin, D., Kholodov, A., Konstantinov, P., Kröger, T., Lambiel, C., Lanckman, J.-P., Luo, D., Malkova, G., Meiklejohn, I., Moskalenko, N., Oliva, M., Phillips, M., Ramos, M., Sannel, A. B. K., Sergeev, D., Seybold, C., Skryabin, P., Vasiliev, A., Wu, Q., Yoshikawa, K., Zheleznyak, M., and Lantuit, H.: Permafrost is warming at a global scale, Nat. Commun., 10, 1-11, https://doi.org/10.1038/s41467-018-08240-4, 2019.

Bjorkman, A. D., Myers-Smith, I. H., Elmendorf, S. C., Normand, S., Rüger, N., Beck, P. S. A., Blach-Overgaard, A., Blok, D., Cornelissen, J. H. C., Forbes, B. C., Georges, D., Goetz, S. J., Guay, K. C., Henry, G. H. R., HilleRisLambers, J., Hollister, R. D., Karger, D. N., Kattge, J., Manning, P., Prevéy, J. S., Rixen, C., Schaepman-Strub, G., Thomas, H. J. D., Vellend, M., Wilmking, M., Wipf, S., Carbognani, M., Hermanutz, L., Lévesque, E., Molau, U., Petraglia, A., Soudzilovskaia, N. A., Spasojevic, M. J., Tomaselli, M., Vowles, T., Alatalo, J. M., Alexander, H. D., Anadon-Rosell, A., Angers-Blondin, S., Beest, M. te, Berner, L., Björk, R. G., Buchwal, A., Buras, A., Christie, K., Cooper, E. J., Dullinger, S., Elberling, B., Eskelinen, A., Frei, E. R., Grau, O., Grogan, P., Hallinger, M., Harper, K. A., Heijmans, M. M. P. D., Hudson, J., Hülber, K., Iturrate-Garcia, M., Iversen, C. M., Jaroszynska, F., Johnstone, J. F., Jørgensen, R. H., Kaarlejärvi, E., Klady, R., Kuleza, S., Kulonen, A., Lamarque, L. J., Lantz, T., Little, C. J., Speed, J. D. M., Michelsen, A., Milbau, A., Nabe-Nielsen, J., Nielsen, S. S., Ninot, J. M., Oberbauer, S. F., Olofsson, J., Onipchenko, V. G., Rumpf, S. B., Semenchuk, P., Shetti, R., Collier, L. S., Street, L. E., Suding, K. N., Tape, K. D., Trant, A., Treier, U. A., Tremblay, J.-P., Tremblay, M., Venn, S., Weijers, S., Zamin, T., Boulanger-Lapointe, N., Gould, W. A., Hik, D. S., Hofgaard, A., Jónsdóttir, I. S., Jorgenson, J., Klein, J., et al.: Plant functional trait change across a warming tundra biome, Nature, 562, 57-62, https://doi.org/10.1038/s41586-0180563-7, 2018.

Bronaugh, D. and Werner, A.: zyp: Zhang + Yue-Pilon trends package, Pacific Climate Impacts Consortium, available at: https://CRAN.R-project.org/package=zyp (last access: 28 February 2020), 2013.

Calmels, D., Gaillardet, J., Brenot, A., and France-Lanord, C.: Sustained sulfide oxidation by physical erosion processes in the Mackenzie River basin: Climatic perspectives, Geology, 35, 1003-1006, https://doi.org/10.1130/G24132A.1, 2007.

Campeau, A., Bishop, K., Nilsson, M. B., Klemedtsson, L., Laudon, H., Leith, F. I., Öquist, M., and Wallin, M. B.: Stable Carbon Isotopes Reveal Soil-Stream DIC Linkages in Contrasting Headwater Catchments, J. Geophys. Res.-Biogeo., 123, 149167, https://doi.org/10.1002/2017JG004083, 2018.

Clark, I. D. and Fritz, P.: Environmental isotopes in hydrogeology, CRC Press/Lewis Publishers, Boca Raton, FL, 1997.

Crawford, J. T., Striegl, R. G., Wickland, K. P., Dornblaser, M. M., and Stanley, E. H.: Emissions of carbon dioxide and methane from a headwater stream network of interior Alaska, J. Geophys. Res.-Biogeo., 118, 482-494, https://doi.org/10.1002/jgrg.20034, 2013.

Cray, H. A. and Pollard, W. H.: Vegetation Recovery Patterns Following Permafrost Disturbance in a Low Arctic Setting: Case Study of Herschel Island, Yukon, Canada, Arct. Antarct. 
Alp. Res., 47, 99-113, https://doi.org/10.1657/AAAR0013-076, 2015.

Descolas-Gros, C. and Fontungne, M.: Stable carbon isotope fractionation by marine phytoplankton during photosynthesis, Plant Cell Environ., 13, 207-218, https://doi.org/10.1111/j.13653040.1990.tb01305.x, 1990.

Didan, K.: MOD13Q1 MODIS/Terra Vegetation Indices 16-Day L3 Global 250m SIN Grid V006 [Data set], NASA EOSDIS Land Processes DAAC, https://doi.org/doi: 10.5067/MODIS/MOD13Q1.006, 2015.

Doctor, D. H., Kendall, C., Sebestyen, S. D., Shanley, J. B., Ohte, N., and Boyer, E. W.: Carbon isotope fractionation of dissolved inorganic carbon (DIC) due to outgassing of carbon dioxide from a headwater stream, Hydrol. Process., 22, 2410-2423, https://doi.org/10.1002/hyp.6833, 2008.

Drake, T. W., Tank, S. E., Zhulidov, A. V., Holmes, R. M., Gurtovaya, T., and Spencer, R. G. M.: Increasing Alkalinity Export from Large Russian Arctic Rivers, Environ. Sci. Technol., 52, 8302-8308, https://doi.org/10.1021/acs.est.8b01051, 2018a.

Drake, T. W., Guillemette, F., Hemingway, J. D., Chanton, J. P., Podgorski, D. C., Zimov, N. S., and Spencer, R. G. M.: The Ephemeral Signature of Permafrost Carbon in an Arctic Fluvial Network, J. Geophys. Res.-Biogeo., 123, 1-11, https://doi.org/10.1029/2017JG004311, 2018b.

Duk-Rodkin, A. and Hughes, O. L.: Surficial geology, Fort McPherson-Bell River, Yukon-Northwest Territories, Geological Survey of Canada, Ottawa, Canada, 1992.

Evans, J. S., Oakleaf, J., Cushman, S. A., and Theobald, D.: An ArcGIS Toolbox for Surface Gradient and Geomorphometric Modeling, version 2.0-0, available at: http://evansmurphy.wix.com/ evansspatial (last access: 2 December 2015), 2014.

Gaillardet, J., Dupré, B., Louvat, P., and Allegre, C. J.: Global silicate weathering and $\mathrm{CO}_{2}$ consumption rates deduced from the chemistry of large rivers, Chem Geol., 159, 3-30, https://doi.org/10.1016/S0009-2541(99)00031-5, 1999.

Gentsch, N., Mikutta, R., Shibistova, O., Wild, B., Schnecker, J., Richter, A., Urich, T., Gittel, A., Šantrůčková, H., Bárta, J., Lashchinskiy, N., Mueller, C. W., Fuß, R., and Guggenberger, G.: Properties and bioavailability of particulate and mineral-associated organic matter in Arctic permafrost soils, Lower Kolyma Region, Russia, Eur. J. Soil Sci., 66, 722-734, https://doi.org/10.1111/ejss.12269, 2015.

Gordon, N. D., McMahon, T. A., Finlayson, B. L., Gippel, C. J., and Nathan, R. J. (eds.): Stream hydrology: an introduction for ecologists, 2nd edn., Wiley, Chichester, West Sussex, England; Hoboken, N.J., 2004.

Hamilton, S. K. and Ostrom, N. E.: Measurement of the stable isotope ratio of dissolved $\mathrm{N}_{2}$ in ${ }^{15} \mathrm{~N}$ tracer experiments, Limnol. Oceanogr.-Meth., 5, 233-240, 2007.

Hesslein, R. H., Rudd, J. W. M., Kelly, C., Ramlal, P., and Hallard, K. A.: Carbon dioxide pressure in surface waters of Canadian lakes, in: Air-Water Mass Transfer: Selected Papers from the Second International Symposium on Gas Transfer at Water Surfaces, edited by: Wilhelms, S. C. and Gulliver, J. S., American Society of Civil Engineers, New York, New York, 413-431, 1991.

Hilton, R. G. and West, A. J.: Mountains, erosion and the carbon cycle, Nat. Rev. Earth Environ., 1, 284-299, https://doi.org/10.1038/s43017-020-0058-6, 2020.
Hitchon, B. and Krouse, H. R.: Hydrogeochemistry of the surface waters of the Mackenzie River drainage basin, Canada-III. Stable isotopes of oxygen, carbon and sulphur, Geochim. Cosmochim. Ac., 36, 1337-1357, 1972.

Horgby, Å., Boix Canadell, M., Ulseth, A. J., Vennemann, T. W., and Battin, T. J.: High-Resolution Spatial Sampling Identifies Groundwater as Driver of $\mathrm{CO}_{2}$ Dynamics in an Alpine Stream Network, J. Geophys. Res.-Biogeo., 124, 1961-1976, https://doi.org/10.1029/2019JG005047, 2019.

Hornby, D. D.: RivEX (Version 10.25), available at: http://www. rivex.co.uk (last access: 21 February 2020), 2017.

Hotchkiss, E. R., Hall Jr, R. O., Sponseller, R. A., Butman, D., Klaminder, J., Laudon, H., Rosvall, M., and Karlsson, J.: Sources of and processes controlling $\mathrm{CO}_{2}$ emissions change with the size of streams and rivers, Nat. Geosci., 8, 696-699, https://doi.org/10.1038/ngeo2507, 2015.

Huete, A., Didan, K., Miura, T., Rodriguez, E. P., Gao, X., and Ferreira, L. G.: Overview of the radiometric and biophysical performance of the MODIS vegetation indices, Remote Sens. Environ., 83, 195-213, https://doi.org/10.1016/S0034-4257(02)00096-2, 2002.

Hutchins, R. H. S., Prairie, Y. T., and del Giorgio, P. A.: LargeScale Landscape Drivers of $\mathrm{CO}_{2}, \mathrm{CH}_{4}, \mathrm{DOC}$, and DIC in Boreal River Networks, Global Biogeochem. Cy., 33, 125-142, https://doi.org/10.1029/2018GB006106, 2019.

Hutchins, R. H. S., Tank, S. E., Olefeldt, D., Quinton, W. L., Spence, C., Dion, N., Estop-Aragonés, C., and Mengistu, S. G.: Fluvial $\mathrm{CO}_{2}$ and $\mathrm{CH}_{4}$ patterns across wildfire-disturbed ecozones of subarctic Canada: Current status and implications for future change, Glob. Change Biol., 26, 2304-2319, https://doi.org/10.1111/gcb.14960, 2020.

Kendall, C., Doctor, D. H., and Young, M. B.: Environmental Isotope Applications in Hydrologic Studies, in: Treatise on Geochemistry, vol. 7, edited by: Holland, H. D. and Turekian, K. K., Elsevier, Oxford, 273-327, 2014.

Kokelj, S. V., Lacelle, D., Lantz, T. C., Tunnicliffe, J., Malone, L., Clark, I. D., and Chin, K. S.: Thawing of massive ground ice in mega slumps drives increases in stream sediment and solute flux across a range of watershed scales, J. Geophys. Res.-Earth, 118, 681-692, https://doi.org/10.1002/jgrf.20063, 2013.

Kokelj, S. V., Tunnicliffe, J., Lacelle, D., Lantz, T. C., Chin, K. S., and Fraser, R.: Increased precipitation drives mega slump development and destabilization of ice-rich permafrost terrain, northwestern Canada, Global Biogeochem. Cy., 129, 56-68, https://doi.org/10.1016/j.gloplacha.2015.02.008, 2015.

Kokelj, S. V., Lantz, T. C., Tunnicliffe, J., Segal, R., and Lacelle, R.: Climate-driven thaw of permafrost preserved glacial landscapes, northwestern Canada, Geology, 45, 371-374, https://doi.org/10.1130/G38626.1, 2017a.

Kokelj, S. V., Tunnicliffe, J. F., and Lacelle, D.: The Peel Plateau of Northwestern Canada: An Ice-Rich Hummocky Moraine Landscape in Transition, in: Landscapes and Landforms of Western Canada, edited by: Slaymaker, O., Springer International Publishing, Cham, 109-122, 2017b.

Kuznetsova, A., Brockhoff, P. B., and Christensen, R. H. B.: Package "ImerTest.", The Comprehensive R Archive Network, 2018.

Lacelle, D., Fontaine, M., Pellerin, A., Kokelj, S. V., and Clark, I. D.: Legacy of Holocene Landscape Changes on Soil Biogeochemistry: A Perspective From Paleo-Active Layers in North- 
western Canada, J. Geophys. Res.-Biogeo., 124, 2662-2679, https://doi.org/10.1029/2018JG004916, 2019.

Lafrenière, M. J. and Sharp, M. J.: The Concentration and Fluorescence of Dissolved Organic Carbon (DOC) in Glacial and Nonglacial Catchments: Interpreting Hydrological Flow Routing and DOC Sources, Arct. Antarct. Alp. Res., 36, 156-165, 2004.

Lehn, G. O., Jacobson, A. D., Douglas, T. A., McClelland, J. W., Barker, A. J., and Khosh, M. S.: Constraining seasonal active layer dynamics and chemical weathering reactions occurring in North Slope Alaskan watersheds with major ion and isotope $\left(\delta^{34} \mathrm{~S}_{\mathrm{SO} 4}, \delta^{13} \mathrm{C}_{\mathrm{DIC}},{ }^{87} \mathrm{Sr} /{ }^{86} \mathrm{Sr}, \delta^{44 / 40} \mathrm{Ca}\right.$, and $\delta^{44 / 42} \mathrm{Ca}$ ) measurements, Geochim. Cosmochim. Ac., 217, 399420, https://doi.org/10.1016/j.gca.2017.07.042, 2017.

Levenstein, B., Culp, J. M., and Lento, J.: Sediment inputs from retrogressive thaw slumps drive algal biomass accumulation but not decomposition in Arctic streams, NWT, Freshwater Biol., 63, 1300-1315, https://doi.org/10.1111/fwb.13158, 2018.

Littlefair, C. A., Tank, S. E., and Kokelj, S. V.: Retrogressive thaw slumps temper dissolved organic carbon delivery to streams of the Peel Plateau, NWT, Canada, Biogeosciences, 14, 5487-5505, https://doi.org/10.5194/bg-14-5487-2017, 2017.

Lurry, D. L. and Kolbe, C. M.: Interagency Field Manual for the Collection of Water-Quality Data, USGS, United States Geological Survey, Austin, TX, 2000.

Malone, L., Lacelle, D., Kokelj, S., and Clark, I. D.: Impacts of hillslope thaw slumps on the geochemistry of permafrost catchments (Stony Creek watershed, NWT, Canada), Chem. Geol., 356, 38 49, https://doi.org/10.1016/j.chemgeo.2013.07.010, 2013.

Millero, F. J.: The thermodynamics of the carbonate system in seawater, Geochim. Cosmochim. Ac., 43, 1651-1661, 1979.

Mook, W. G., Bommerson, J. C., and Staverman, W. H.: Carbon isotope fractionation between dissolved bicarbonate and gaseous carbon dioxide, Earth Planet. Sc. Lett., 22, 169-176, 1974.

Norris, D. K.: Geology of the Northern Yukon and Northwestern District of Mackenzie, Geological Survey of Canada, Ottawa, Canada, 1985.

Olefeldt, D., Goswami, S., Grosse, G., Hayes, D., Hugelius, G., Kuhry, P., McGuire, A. D., Romanovsky, V. E., Sannel, A. B. K., Schuur, E. A. G., and Turetsky, M. R.: Circumpolar distribution and carbon storage of thermokarst landscapes, Nat. Commun., 7, 13043, https://doi.org/10.1038/ncomms13043, 2016.

Parkhurst, D. I. and Appelo, C. A. J.: Description of input and examples for PHREEQC version 3 - A computer program for speciation, batch-reaction, one-dimensional transport, and inverse geochemical calculations, vol. A43, p. 497, U.S. Geological Survey, available at: http://pubs.usgs.gov/tm/06/a43 (last access: 13 September 2018), 2013.

Pierrot, D., Lewis, E., and Wallace, D. W. R.: MS Excel program developed for $\mathrm{CO}_{2}$ system calculations, available at: https://doi.org/10.3334/CDIAC/otg.CO2SYS_XLS_CDIAC105a Carbon Dioxide Information Analysis Center, Oak Ridge National Laboratory, US Department of Energy, Oak Ridge, Tennessee, 2006.

Piper, A. M.: A graphic procedure in the geochemical interpretation of water-analyses, Eos T. Am. Geophys. Un., 25, 914, https://doi.org/10.1029/TR025i006p00914, 1944.

Poulin, B. A., Ryan, J. N., and Aiken, G. R.: Effects of Iron on Optical Properties of Dissolved Organic Matter, Environ. Sci. Technol., 48, 10098-10106, https://doi.org/10.1021/es502670r, 2014.
R Core Team: R: A Language and Environment for Statistical Computing, R Foundation for Statistical Computing, Vienna, Austria, available at: http://www.r-project.org/ (last access: 15 September 2020), 2018.

Rawlins, M. A., Steele, M., Holland, M. M., Adam, J. C., Cherry, J. E., Francis, J. A., Groisman, P. Y., Hinzman, L. D., Huntington, T. G., Kane, D. L., Kimball, J. S., Kwok, R., Lammers, R B., Lee, C. M., Lettenmaier, D. P., McDonald, K. C., Podest, E., Pundsack, J. W., Rudels, B., Serreze, M. C., Shiklomanov, A., Skagseth, Ø., Troy, T. J., Vörösmarty, C. J., Wensnahan, M., Wood, E. F., Woodgate, R., Yang, D., Zhang, K., and Zhang, T.: Analysis of the Arctic System for Freshwater Cycle Intensification: Observations and Expectations, J. Climate, 23, 5715-5737, https://doi.org/10.1175/2010JCLI3421.1, 2010.

Riley, S. J., DeGloria, S. D., and Elliot, R.: A terrain ruggedness index that quantifies topographic heterogeneity, Int. J. Sci., 5, 23 27, 1999.

Sander, R.: Compilation of Henry's law constants (version 4.0) for water as solvent, Atmos. Chem. Phys., 15, 4399-4981, https://doi.org/10.5194/acp-15-4399-2015, 2015.

Schuur, E. A. G., McGuire, A. D., Schädel, C., Grosse, G., Harden, J. W., Hayes, D. J., Hugelius, G., Koven, C. D., Kuhry, P., Lawrence, D. M., Natali, S. M., Olefeldt, D., Romanovsky, V. E., Schaefer, K., Turetsky, M. R., Treat, C. C., and Vonk, J. E.: Climate change and the permafrost carbon feedback, Nature, 520, 171-179, https://doi.org/10.1038/nature14338, 2015.

Segal, R. A., Lantz, T. C., and Kokelj, S. V.: Acceleration of thaw slump activity in glaciated landscapes of the Western Canadian Arctic, Environ. Res. Lett., 11, 034025, https://doi.org/10.1088/1748-9326/11/3/034025, 2016.

Serreze, M. C. and Barry, R. G.: Processes and impacts of Arctic amplification: A research synthesis, Global Biogeochem. Cy., 77, 85-96, https://doi.org/10.1016/j.gloplacha.2011.03.004, 2011.

Shakil, S., Tank, S. E., Kokelj, S. V., Vonk, J. E., and Zolkos, S.: Particulate dominance of organic carbon mobilization from thaw slumps on the Peel Plateau, NT: Quantification and implications for stream systems and permafrost carbon release, Environ. Res. Lett., accepted, https://doi.org/10.1088/1748-9326/abac36, 2020.

Sharp, M., Tranter, M., Brown, G. H., and Skidmore, M.: Rates of chemical denudation and $\mathrm{CO}_{2}$ drawdown in a glacier-covered alpine catchment, Geology, 23, 61-64, 1995.

St. Pierre, K. A., St. Louis, V. L., Schiff, S. L., Lehnherr, I., Dainard, P. G., Gardner, A. S., Aukes, P. J. K., and Sharp, M. J.: Proglacial freshwaters are significant and previously unrecognized sinks of atmospheric $\mathrm{CO}_{2}$, P. Natl. Acad. Sci. USA, 116, 17690-17695, https://doi.org/10.1073/pnas.1904241116, 2019.

Stallard, R. F. and Edmond, J. M.: Geochemistry of the Amazon: 2. The Influence of Geology and Weathering Environment on the Dissolved Load, J. Geophys. Res., 88, 9671-9688, 1983.

Striegl, R. G., Dornblaser, M. M., Aiken, G. R., Wickland, K. P., and Raymond, P. A.: Carbon export and cycling by the Yukon, Tanana, and Porcupine rivers, Alaska, 2001-2005, Water Resour Res., 43, 1-9, https://doi.org/10.1029/2006WR005201, 2007.

Stubbins, A., Silva, L. M., Dittmar, T., and Van Stan, J. T.: Molecular and Optical Properties of Tree-Derived Dissolved Organic Matter in Throughfall and Stemflow from Live Oaks and Eastern Red Cedar, Front. Earth Sci., 5, 1-13, https://doi.org/10.3389/feart.2017.00022, 2017. 
Stumm, W. and Morgan, J. J.: Aquatic Chemistry: Chemical Equilibria and Rates in Natural Waters, 3rd edn., John Wiley \& Son, Inc., New York, 1996.

Tank, S. E., Striegl, R. G., McClelland, J. W., and Kokelj, S. V.: Multi-decadal increases in dissolved organic carbon and alkalinity flux from the Mackenzie drainage basin to the Arctic Ocean, Environ. Res. Lett., 11, 054015, https://doi.org/10.1088/17489326/11/5/054015, 2016.

Tank, S. E., Vonk, J. E., Walvoord, M. A., McClelland, J. W., Laurion, I., and Abbott, B. W.: Landscape matters: Predicting the biogeochemical effects of permafrost thaw on aquatic networks with a state factor approach, Permafrost Periglac., 31, 358-370, https://doi.org/10.1002/ppp.2057, 2020.

Toohey, R. C., Herman-Mercer, N. M., Schuster, P. F., Mutter, E. A., and Koch, J. C.: Multidecadal increases in the Yukon River Basin of chemical fluxes as indicators of changing flowpaths, groundwater, and permafrost, Geophys. Res. Lett., 43, 12120-12130, https://doi.org/10.1002/2016GL070817, 2016.

Torres, M. A., Moosdorf, N., Hartmann, J., Adkins, J. F., and West, A. J.: Glacial weathering, sulfide oxidation, and global carbon cycle feedbacks, P. Natl. Acad. Sci. USA, 114, 8716-8721, https://doi.org/10.1073/pnas.1702953114, 2017.

Turetsky, M. R., Abbott, B. W., Jones, M. C., Walter Anthony, K., Olefeldt, D., Schuur, E. A. G., Grosse, G., Kuhry, P., Hugelius, G., Koven, C., Lawrence, D. M., Gibson, C., Sannel, A. B. K., and McGuire, A. D.: Carbon release through abrupt permafrost thaw, Nat. Geosci., 13, 138-143, 2020.

Turner, J. V.: Kinetic fractionation of carbon-13 during calcium carbonate precipitation, Geochim. Cosmochim. Ac., 46, 11831191, https://doi.org/10.1016/0016-7037(82)90004-7, 1982.

van der Sluijs, J., Kokelj, S. V., Fraser, R. H., Tunnicliffe, J., and Lacelle, D.: Permafrost Terrain Dynamics and Infrastructure Impacts Revealed by UAV Photogrammetry and Thermal Imaging, Remote Sens.-Basel, 30, 1-30, https://doi.org/10.3390/rs10111734, 2018.

Vonk, J. E., Tank, S. E., Mann, P. J., Spencer, R. G. M., Treat, C. C., Striegl, R. G., Abbott, B. W., and Wickland, K. P.: Biodegradability of dissolved organic carbon in permafrost soils and aquatic systems: a meta-analysis, Biogeosciences, 12, 69156930, https://doi.org/10.5194/bg-12-6915-2015, 2015.

Vonk, J. E., Tank, S. E., and Walvoord, M. A.: Integrating hydrology and biogeochemistry across frozen landscapes, Nat. Commun., 10, 5377, https://doi.org/10.1038/s41467-019-13361-5, 2019.
Wadham, J. L., Hawkings, J. R., Tarasov, L., Gregoire, L. J., Spencer, R. G. M., Gutjahr, M., Ridgwell, A., and Kohfeld, K. E.: Ice sheets matter for the global carbon cycle, Nat. Commun., 10, 3567, https://doi.org/10.1038/s41467-019-11394-4, 2019.

Walvoord, M. A. and Kurylyk, B. L.: Hydrologic Impacts of Thawing Permafrost - A Review, Vadose Zone J., 15, 1-20, https://doi.org/10.2136/vzj2016.01.0010, 2016.

Weishaar, J. L., Aiken, G. R., Bergamaschi, B. A., Fram, M. S., Fujii, R., and Mopper, K.: Evaluation of Specific Ultraviolet Absorbance as an Indicator of the Chemical Composition and Reactivity of Dissolved Organic Carbon, Environ. Sci. Technol., 37, 4702-4708, https://doi.org/10.1021/es030360x, 2003.

Weiss, R. F.: Carbon dioxide in water and seawater: the solubility of a non-ideal gas, Mar. Chem., 2, 203-215, 1974.

Wiesenburg, D. A. and Guinasso, N. L.: Equilibrium solubilities of methane, carbon monoxide, and hydrogen in water and sea water, J. Chem. Eng. Data, 24, 356-360, 1979.

Yue, S., Pilon, P., Phinney, B., and Cavadias, G.: The influence of autocorrelation on the ability to detect trend in hydrological series, Hydrol. Process., 16, 1807-1829, https://doi.org/10.1002/hyp.1095, 2002.

Zhang, J., Quay, P. D., and Wilbur, D. O.: Carbon isotope fractionation during gas-water exchange and dissolution of $\mathrm{CO}_{2}$, Geochim. Cosmochim. Ac., 59, 107-114, 1995.

Zolkos, S. and Tank, S. E.: Experimental Evidence That Permafrost Thaw History and Mineral Composition Shape Abiotic Carbon Cycling in Thermokarst-Affected Stream Networks, Front. Earth Sci., 8, 1-17, https://doi.org/10.3389/feart.2020.00152, 2020.

Zolkos, S., Tank, S. E., and Kokelj, S. V.: Mineral Weathering and the Permafrost Carbon-Climate Feedback, Geophys. Res. Lett., 45, 9623-9632, https://doi.org/10.1029/2018GL078748, 2018.

Zolkos, S., Tank, S. E., Striegl, R. G., and Kokelj, S. V.: Thermokarst Effects on Carbon Dioxide and Methane Fluxes in Streams on the Peel Plateau (NWT, Canada), J. Geophys. Res.-Biogeo., 124, 1781-1798, https://doi.org/10.1029/2019JG005038, 2019.

Zuur, A. F. (ed.): Mixed effects models and extensions in ecology with R, Springer, New York, NY, 2009.

Zuur, A. F., Ieno, E. N., and Elphick, C. S.: A protocol for data exploration to avoid common statistical problems, Methods Ecol. Evol., 1, 3-14, https://doi.org/10.1111/j.2041210X.2009.00001.x, 2010. 